\title{
Social-environmental analysis of methane in the South China Sea and bordering countries
}

\author{
Hsiao-Chun Tseng, Alice Newton, Chen-Tung Arthur Chen, Alberto V. Borges, and \\ T. Angel DelValls
}

\begin{abstract}
This study is a preliminary assessment of the greenhouse effect of methane $\left(\mathrm{CH}_{4}\right)$ emissions in the South China Sea (SCS) on human welfare using the driver-pressure-stateimpact-response (DPSIR) framework and the systems approach framework (SAF). The SCS is surrounded by nations of the Asia-Pacific region that are currently experiencing rapid urbanization, industrialization, and economic growth, and is one of the most contested maritime areas of the world. Climate change may aggravate regional tensions, promote natural disasters, create climate refugees, and reduce food security by reducing the size of fish catches and crops. International environmental protection, as well as the mitigation of, and adaptation to, climate change not only protect environmental sustainability, but also provide an international platform of cooperation for all countries around the SCS. The study analyzed the economic drivers and human activities that cause the pressure on the environment and increase $\mathrm{CH}_{4}$ emissions in the region. In addition, the possible future impact of climate change on human welfare is also discussed in the study. Finally, the study identified eight management responses across various spatial and temporal scales that can be useful in addressing the issue of greenhouse gas $\left(\mathrm{CH}_{4}\right)$ in the SCS.

Key words: South China Sea, $\mathrm{CH}_{4}$, greenhouse gases, driver-pressure-state-impact-response, systems approach framework.
\end{abstract}

\section{Introduction}

The Earth's climate system is powered by solar radiation. Infrared radiation from the sun that is emitted from the Earth's surface is largely absorbed by certain atmospheric constituents: water vapor $\left(\mathrm{H}_{2} \mathrm{O}\right)$, carbon dioxide $\left(\mathrm{CO}_{2}\right)$, methane $\left(\mathrm{CH}_{4}\right)$, nitrous oxide $\left(\mathrm{N}_{2} \mathrm{O}\right)$, and other greenhouse gases (GHGs). Atmospheric GHGs retain the heat from the sun and insulate the Earth. Human activities have a huge influence on the global carbon cycle. Since the industrial era, as the use of machinery has increased, demand for fossil fuels,

Received 30 December 2017. Accepted 24 June 2018.

H.-C. Tseng. Institute of Marine Environment and Ecology, National Taiwan Ocean University, Keelung 202, Taiwan; CIMA, Campus de Gambelas, Universidade do Algarve, 8005-139 Faro, Portugal; Department of Oceanography, National Sun Yat-sen University, Kaohsiung 804, Taiwan; UNESCO UNITWIN/WiCop, Physical Chemistry Department, Faculty of Marine and Environmental Sciences, Polígono río San Pedro s/n, University of Cadiz, 11519, Puerto Real, Cadiz, Spain. A. Newton. CIMA, Campus de Gambelas, Universidade do Algarve, 8005-139 Faro, Portugal; NILU-IMPEC, Box 100, 2027 Kjeller, Norway.

C.-T. Arthur Chen. Department of Oceanography, National Sun Yat-sen University, Kaohsiung 804, Taiwan. A.V. Borges. Université de Liège, Unité d’Océanographie Chimique, Institut de Physique (B5), B-4000, Belgium.

T.A. DelValls. UNESCO UNITWIN/WiCop, Physical Chemistry Department, Faculty of Marine and Environmental Sciences, Polígono río San Pedro s/n, University of Cadiz, 11519, Puerto Real, Cadiz, Spain; Department of Ecotoxicology, Santa Cecília University (UNISANTA), Santos, São Paulo, Brazil.

Corresponding author: Chen-Tung Arthur Chen (e-mail: ctchen@mail.nsysu.edu.tw).

Copyright remains with the author(s) or their institution(s). This work is licensed under a Creative Commons Attribution 4.0 International License (CC BY 4.0), which permits unrestricted use, distribution, and reproduction in any medium, provided the original author(s) and source are credited. 
deforestation, and intense agriculture, atmospheric GHG concentrations have been increasing and the climate system has changed (IPCC 2013).

$\mathrm{CH}_{4}$, the second most important GHG after $\mathrm{CO}_{2}$, has a global warming potential over a 20-year time frame $\left(\mathrm{GWP}_{20}\right)$ that is 86 times that of $\mathrm{CO}_{2}$, and accounts for $32 \%$ of anthropogenic global radiative forcing (Saunois et al. 2016). The global atmospheric $\mathrm{CH}_{4}$ concentration has increased significantly from a pre-industrial value of $722 \pm 25 \mathrm{ppb}$ in 1750 to $1803 \pm 2 \mathrm{ppb}$ in 2011 (IPCC 2013). This increase in $\mathrm{CH}_{4}$ concentration is probably caused by human activities (IPCC 2013). A massive increase in animal farming, especially ruminants (Barnosky 2008), emissions associated with fossil fuel extraction and use, the expansion of rice paddy agriculture, and emissions from landfills and waste, are the dominant anthropogenic sources of $\mathrm{CH}_{4}$ (Fig. 1). According to IPCC (2013), anthropogenic sources contribute at present between $50 \%$ and $65 \%$ of all atmospheric $\mathrm{CH}_{4}$ sources.

Most $\mathrm{CH}_{4}$ in marine areas is generated either by biological production in water or externally, including by diffusion from the organic-rich anaerobic sediment (Borges et al. 2017), and inputs of methane-rich freshwater (Scranton and McShane 1991). In the ocean, the redox state of the environment is an important factor in determining the biological cycling of $\mathrm{CH}_{4}$. Because this redox state is determined by the ambient oxygen $\left(\mathrm{O}_{2}\right)$ concentration, changes in $\mathrm{O}_{2}$ distribution may alter the strength of $\mathrm{CH}_{4}$ sources. Such changes in the oceanic $\mathrm{O}_{2}$ distribution may be caused by changes in circulation or stratification in response to global warming, and (or) by the elevated respiration of organic matter as a result of an increased supply of nutrients from land (Naqvi et al. 2010; Borges et al. 2017) or the upwelling of increasingly nutrient-rich subsurface waters (Lui et al. 2014).

The open ocean is a much weaker source of $\mathrm{CH}_{4}$ to the atmosphere $\left(0.4-1.8 \mathrm{Tg}^{-1} \mathrm{CH}_{4} \mathrm{yr}^{-1}\right)$ than other natural (230-350 $\mathrm{Tg} \mathrm{CH}_{4} \mathrm{yr}^{-1}$ ) and anthropogenic (330-335 $\mathrm{Tg} \mathrm{CH}_{4} \mathrm{yr}^{-1}$ ) $\mathrm{CH}_{4}$ sources, and coastal regions are greater sources of $\mathrm{CH}_{4}$ to the atmosphere than are open oceanic waters (Kirschke et al. 2013). The high $\mathrm{CH}_{4}$ concentrations in surface waters of continental shelves arise from direct $\mathrm{CH}_{4}$ inputs from rivers, estuaries, and sediments wherever methanogenesis is sustained by extensive sedimentation of organic matter (Upstill-Goddard et al. 2000; Borges et al. 2017). Natural gas and $\mathrm{CH}_{4}$ gas hydrates seep from continental shelves and slopes as another source of $\mathrm{CH}_{4}$ in coastal regions. $\mathrm{CH}_{4}$ gas hydrates are ice-like solids that are composed of water molecules that encase $\mathrm{CH}_{4}$ and other gases. Because the quantity of $\mathrm{CH}_{4}$ gas within hydrate-bearing sediments is substantial, $\mathrm{CH}_{4}$ gas hydrates have been considered to be potential sources of energy (Boswell 2009). Biogenic or thermogenic $\mathrm{CH}_{4}$ can accumulate in large quantities in the sub-surface seabed (gassy sediments) in deep and shallow areas, and can be released as bubbles (gas flares) or by pore water diffusion (Borges et al. 2016).

The release of more GHGs into the atmosphere will increase global warming, causing the thawing of permafrost and the destabilization of marine $\mathrm{CH}_{4}$ gas hydrates (Archer 2007; Kennedy et al. 2008; Archer et al. 2009; O'Connor et al. 2010), which will have a huge effect on the climate. As $\mathrm{CH}_{4}$ has greater global warming potential than $\mathrm{CO}_{2}$, the release of $\mathrm{CH}_{4}$ from thawing permafrost and gas hydrates may magnify global warming. However, because $\mathrm{CH}_{4}$ has a short residence time in the atmosphere (around 10 years), if we act on $\mathrm{CH}_{4}$ emission reduction we can mitigate climate change on very short time scales, unlike $\mathrm{CO}_{2}$ that has a much longer residence time in the atmosphere (about 100 years).

Human activities influence the ecosystem and have caused the environment to change. Environmental change affects human livelihoods and well-being. The impact of increasing $\mathrm{CH}_{4}$ concentrations in the atmosphere and the ocean on human welfare is uncertain. Around $60 \%$ of the South China Sea (SCS) bottom is continental shelf and upper slope. Those areas are strongly influenced by human activities and account for approximately $72 \%$ of $\mathrm{CH}_{4}$ emission from the SCS (Tseng et al. 2017). As the SCS has a large percentage of 
Fig. 1. Conceptual diagram representing sources of $\mathrm{CH}_{4}$.

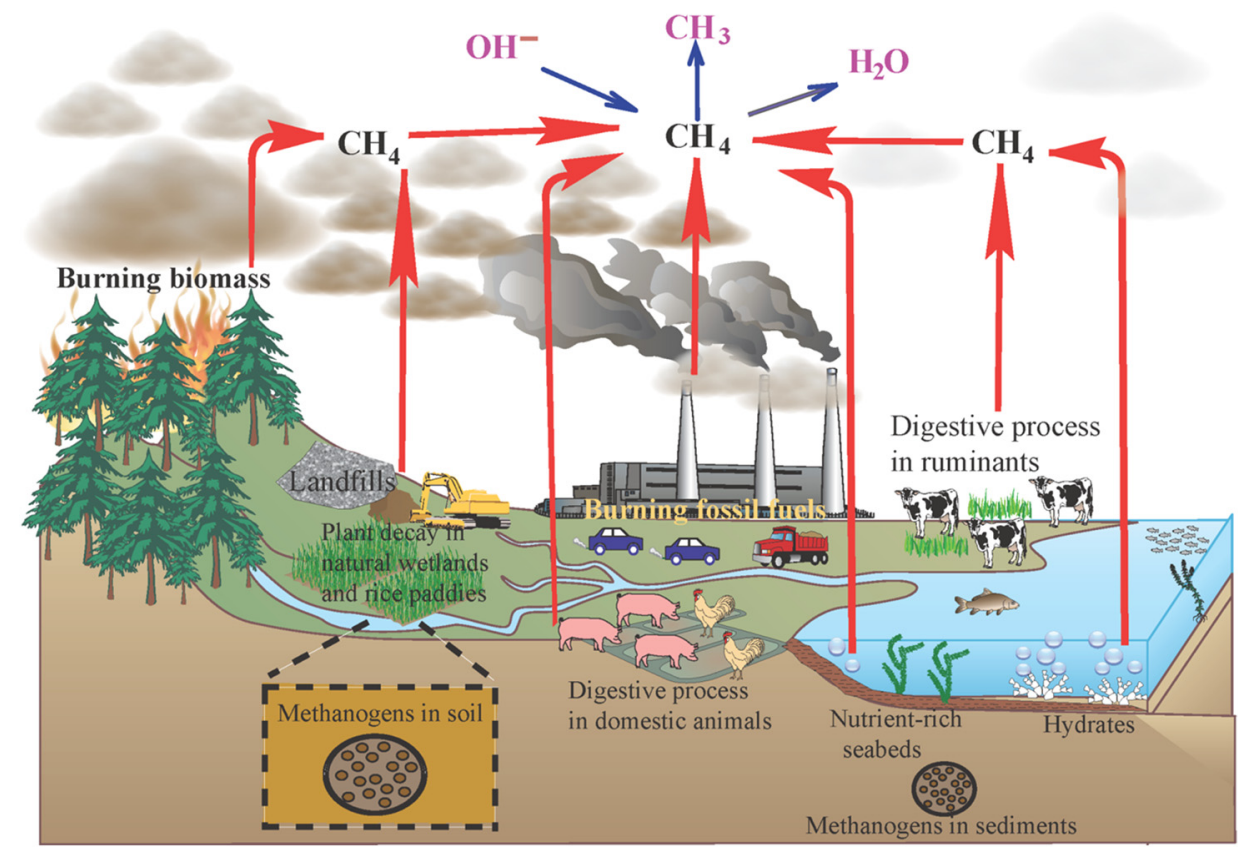

coastal regions and is strongly affected by anthropogenic activities, the situation in the SCS may have become more severe compared with the open ocean. In addition, coastal $\mathrm{CH}_{4}$ emissions may increase in response to global warming (Zhang and Zhai 2015; Borges et al. 2016, 2017). However, because anthropogenic activities strongly influence the coastal regions, we could reduce $\mathrm{CH}_{4}$ emission by changing our behaviors and it may help mitigate climate change. This paper analyzes the issue of $\mathrm{CH}_{4}$ in the SCS in the context of global change, using a social-environmental approach and scientific and economic data. It considers both global change of the human (population and organic matter inputs) and the environmental (climate change and GHGs, for example) dimensions. It also provides management recommendations to reduce $\mathrm{CH}_{4}$ emissions in the SCS.

\section{Methods of social-environmental analysis}

Climate change is an environmental issue that also involves human activities. Therefore, two main social-environmental frameworks are used in the analysis herein. They are the system approach framework (SAF; Hopkins et al. 2011; Newton 2012) and a modified Driver-Pressure-State-Impact-Response (DPSIR; Gari et al. 2015; Patrício et al. 2016) framework. A combined social-environmental analysis of carbon fluxes has not previously been attempted. This research uses the following parts of the SAF (Hopkins et al. 2011): issue definition, system definition and design, and system appraisal (IPCC 2013). The DPSIR framework, adopted by the European Environment Agency and others (Elliott 2002; Rogers and Greenaway 2005; Borja et al. 2006; Maxim et al. 2009; Gray and Elliott 2009; Atkins et al. 2011), describes a framework for assessing the causes, consequences, and responses to change in a holistic way. The modified version of DPSIR (Gari et al. 2015; Patrício et al. 2016) involves economic drivers and human activities, pressures from activities, state of environment, impact on human welfare, and responses of society and management measures. The study analyzed both the scientific data, such as $\mathrm{CH}_{4}$, dissolved organic carbon 
Fig. 2. DPSIR framework (Patrício et al. 2016).

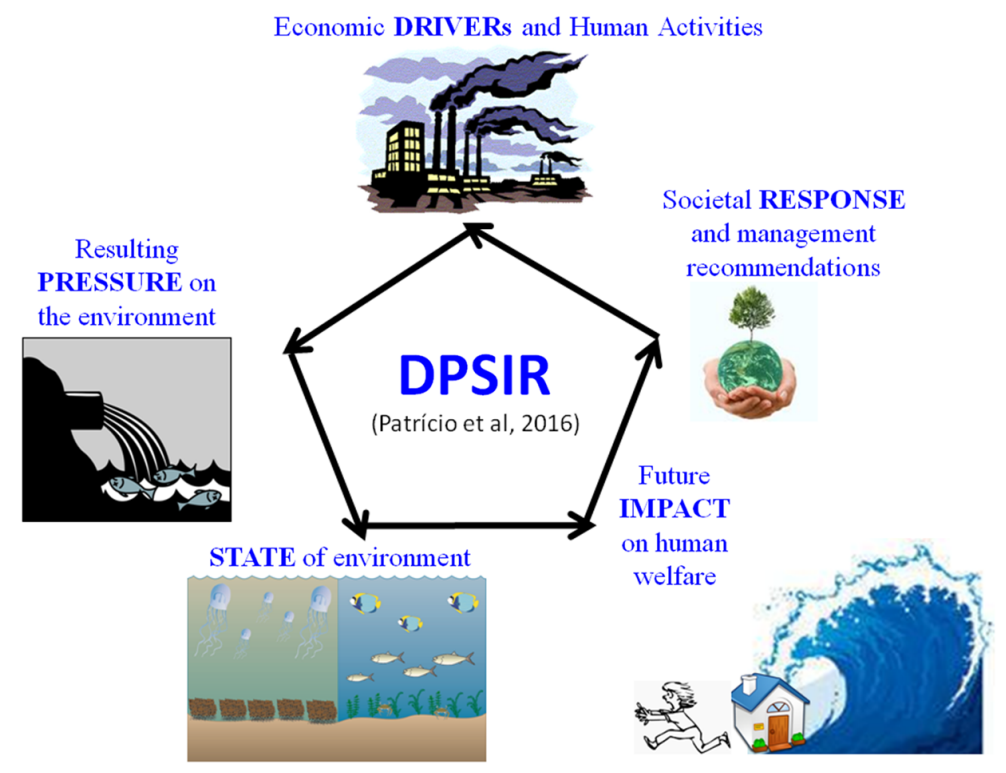

(DOC) and chemical oxygen demand (COD) as well as societal data, such as population, population density, and wastewater treatment rate. The DPSIR analysis (Fig. 2) addresses the following research questions. (i) What are the Drivers and human activities that increase $\mathrm{CH}_{4}$ concentrations in the SCS? (ii) How do those human activities influence (pressure) the environment? (iii) What are the consequences thereof the state of the environment? $(i v)$ What are the impacts on human welfare? $(v)$ Which societal responses and management measures can reduce $\mathrm{CH}_{4}$ emissions from the SCS?

\section{Results of social-environmental analysis}

This section presents the results of the social-environmental analysis under the following headings: issue definition, system definition and design, economic drivers and human activities, resulting pressure on the environment, state of the environment of the SCS, and impact on human welfare.

\subsection{Issue definition (Hopkins et al. 2011)}

Continental shelves and estuaries are responsible for approximately $75 \%$ of global oceanic $\mathrm{CH}_{4}$ emissions (Bange et al. 1994). According to Borges et al. (2016, 2017), the contribution from sedimentary sources in well-mixed coastal zones may be the cause of the higher $\mathrm{CH}_{4}$ emissions from continental shelves and estuaries than from open ocean, especially in areas of hydrocarbon seepage or hydrate destabilization. Industrialization has changed people's lifestyles, especially in developed countries. Human activities have increased the input of organic matter from domestic waste and industry (predominantly agriculture, industrialized animal farming, and aquaculture) into rivers and coastal areas, increasing $\mathrm{CH}_{4}$ concentrations and emissions in the SCS. The estuaries and embayment mark human disturbance, and prominent impacts on the coastal environment and ecosystem have been observed (Liu et al. 2009). The ongoing increasing of eutrophication-induced hypoxia will increase $\mathrm{CH}_{4}$ concentrations in coastal waters and possibly the emission of $\mathrm{CH}_{4}$ into the atmosphere (Bange 2006; Naqvi et al. 2010; Borges et al. 2017). 
Fig. 3. Map of study area and sampling stations.

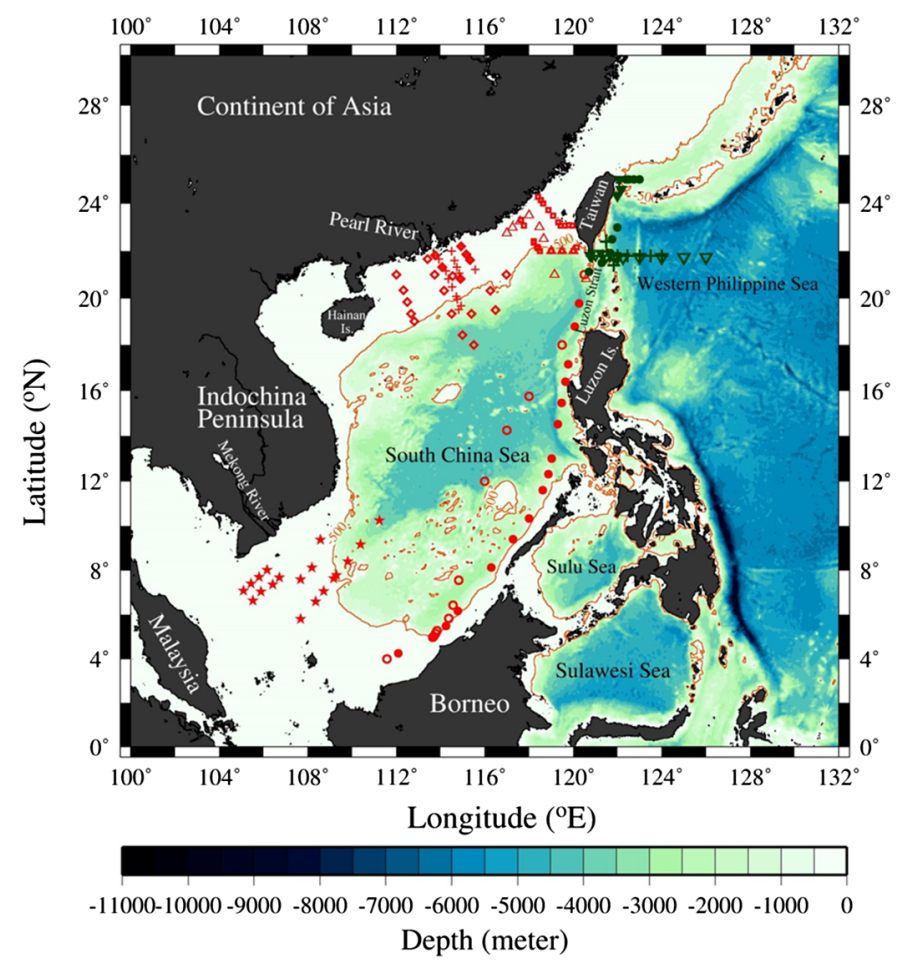

\subsection{System definition and design (Hopkins et al. 2011)}

The SCS (Fig. 3) is the largest marginal sea in the world, with an area of $3.5 \times 10^{6} \mathrm{~km}^{2}$; it is also one of the world's busiest maritime areas (Chen 2013). It is surrounded by nations in the Asia-Pacific region that are currently experiencing rapid urbanization, industrialization, and economic growth, especially China, Indonesia, and Vietnam (Table 1). The SCS, typical of a sea in a tropical climate, has both a deep basin and extensive shelf systems at its northern and southern boundaries, which are associated with large riverine inputs. About 122 major rivers drain $2.5 \times 10^{6} \mathrm{~km}^{2}$ of catchment area and deliver materials, including suspended sediments, nutrients, organic matter and pollutants, to the SCS (Pernetta and Bewers 2013).

Historically, the SCS has been critical to the economic and political stability in Southeast Asia and adjacent regions; today, it is crucial for the environmental sustainability and food security of its surrounding nations. The coastal sub-regions of these nations are home to 270 million people or 5\% of the world's population (Pernetta and Bewers 2013).

\subsection{DPSIR framework (Patrício et al. 2016)}

This study uses the DPSIR framework (Patrício et al. 2016) to the social-environment of the SCS. Human activities (economic drivers) that may be sources of $\mathrm{CH}_{4}$ in the SCS are firstly identified. The way in which those human activities influence the $\mathrm{CH}_{4}$ concentration in the SCS (pressure) is analyzed. The state of the SCS is then elucidated and its possible impact on human welfare considered.

\subsection{Economic drivers - and human activities}

The following sections analyze several anthropogenic sources of $\mathrm{CH}_{4}$, which are (D1) urbanization and increases in municipal solid waste (MSW), (D2) economic growth and 
Table 1. Population, gross national income (GNI), and human development index (HDI) of countries that surround the SCS and amount of municipal solid waste (MSW) generated thereby.

\begin{tabular}{|c|c|c|c|c|c|c|c|c|c|c|c|}
\hline \multirow[b]{2}{*}{ Nation } & \multicolumn{2}{|c|}{ Population (total) } & \multirow{2}{*}{$\begin{array}{l}\text { Annual } \\
\text { Population } \\
\text { growth } \\
\text { rate (\%) }\end{array}$} & \multirow{2}{*}{$\begin{array}{l}\text { Population } \\
\text { ratio on } \\
\text { the SCS } \\
\text { coast (\%) }\end{array}$} & \multicolumn{2}{|c|}{$\begin{array}{l}\text { Urban population } \\
\text { (\% of total) }\end{array}$} & \multicolumn{2}{|c|}{$\begin{array}{l}\text { GNI per capita } \\
\text { (current US\$) }\end{array}$} & \multirow{2}{*}{$\begin{array}{l}2000-2015 \text { GNI } \\
\text { per capita growth } \\
\text { rate (\%) }\end{array}$} & \multirow{2}{*}{$\begin{array}{l}2015 \\
\text { HDI }\end{array}$} & \multirow{2}{*}{$\begin{array}{l}\text { MSW generation } \\
\text { per capita } \\
\text { (kg/capita } \\
\text { per day) }\end{array}$} \\
\hline & 2000 & 2015 & & & 2000 & 2015 & 2000 & 2015 & & & \\
\hline Brunei & 330554 & 423188 & 1.65 & 100.0 & 71.2 & 77.2 & 14800 & 38010 & 156.8 & 0.865 & 0.87 \\
\hline Cambodia & 12197905 & 15577899 & 1.63 & 0.7 & 18.6 & 20.7 & 300 & 1070 & 256.7 & 0.563 & $0.49^{a}$ \\
\hline China & 1260000000 & 1370000000 & 0.55 & 7.9 & 35.9 & 55.6 & 940 & 7930 & 743.6 & 0.738 & 1.00 \\
\hline Hong Kong, China & 6665000 & 7305700 & 0.61 & 100.0 & 100.0 & 100.0 & 26930 & 41000 & 52.2 & 0.917 & 1.99 \\
\hline Indonesia & 212000000 & 258000000 & 1.31 & 8.2 & 42.0 & 53.7 & 560 & 3440 & 514.3 & 0.563 & 0.52 \\
\hline Malaysia & 23420751 & 30331007 & 1.72 & 30.0 & 62.0 & 74.7 & 3420 & 10570 & 209.1 & 0.789 & 1.52 \\
\hline Philippines & 77932247 & 101000000 & 1.71 & 3.9 & 48.0 & 44.4 & 1220 & 3550 & 191.0 & 0.556 & 0.5 \\
\hline Singapore & 4027887 & 5535002 & 2.12 & 100.0 & 100.0 & 100.0 & 23670 & 52090 & 120.1 & 0.925 & 1.49 \\
\hline Taiwan & 22301000 & 23381038 & 0.33 & 35.0 & 69.9 & 77 & 15142 & 23325 & 54.0 & 0.885 & $0.81^{b}$ \\
\hline Thailand & 62693322 & 67959359 & 0.54 & 50.0 & 31.4 & 50.4 & 1990 & 5720 & 187.4 & 0.586 & 1.76 \\
\hline Vietnam & 66016700 & 91703800 & 1.11 & 82.7 & 20.3 & 33.6 & 400 & 1990 & 397.5 & 0.562 & 1.46 \\
\hline
\end{tabular}

Note: Data from The World Bank (2015) and Directorate-General of Budget, Accounting and Statistics, Executive Yuan, R.O.C. (Taiwan) (2018).

${ }^{a}$ Sethy et al. 2014

${ }^{b}$ Lu et al. 2006. 
lifestyle change, (D3) increasing size of animal farming and aquaculture, (D4) agricultural intensification, and (D5) rapid industrial development and the bio-economy.

\section{(D1) Urbanization and increases in MSW}

The Pearl River Delta (PRD), in south China's Guangdong province, has been among the fastest growing regions of China, since China's open-door policy in 1978 and the adoption of economic reform. Urbanization and industrialization have led to increasingly serious environmental problems, exacerbated by the lack of a good urban plan, management, and policy (Yeh and Li 1999; Ouyang et al. 2006). The PRD is the second largest delta in China, with an area of $5.6 \times 10^{4} \mathrm{~km}^{2}$. Owing to the economic growth, people have moved to the PRD for work and the population in the river basin has increased. The population was 21.4 million in 1990, had increased to 47.2 million by 2007 (Wang and Chen 2009), and more than 57 million people by the end of 2013 (The World Bank 2015). According to the Sixth National Population Census of the People's Republic of China, the population density in the PRD was about 1000 people per $\mathrm{km}^{2}$, compared to a national average of 118 people per $\mathrm{km}^{2}$. The high population density, rapid urbanization, and industrialization have put severe stress on the aquatic environment. As the population increases, so does the discharge of chemicals and organic matter. According to Seto (2002), the daily discharge of wastewater had already reached $10.6 \times 10^{6} \mathrm{~m}^{3}$ in 1985 , resulting in eutrophication and red tides. Figure $4 a$ shows that high concentrations of DOC appeared within $200 \mathrm{~km}$ of the Pearl River mouth ${ }^{1}$ (Chen et al. 2008), where populations density increased. In addition, DOC concentration increased positively with cumulative population on the river watershed (Fig. 4b).

\section{(D2) Economic growth and lifestyle change}

China has experienced fast economic growth with an annual gross domestic product (GDP) growth rate of $8 \%$ over the past two decades, the highest rate in recent history (Liu and Savenije 2008). Consumers' income has risen substantially, resulting in rapid dietary change towards more meat consumption (Du et al. 2004; FAO 2006). Chinese diets have shifted from high-carbohydrate foods toward animal products, particularly meat (Du et al. 2004). Meat consumption was low before 1980. Animal products were luxury foods in China and only a few rich people could regularly consume them before that year, but most people can afford them now (Liu and Savenije 2008). With rapid economic growth and a large increase in per capita income, urbanization, and market size, meat consumption rose by a factor of 3.7 from 1980 to 2003 (Huang et al. 1999; Hsu et al. 2002). According to Du et al. (2004), following rapid economic and social change, the nutrition transition (from carbohydrate foods to animal products) accelerated in developing countries. Animals raised for food require more land and water than crops, and they produce more organic waste.

\section{(D3) Increasing size of animal farming and aquaculture}

This section considers animal farming and aquaculture together because they have similar effects on the carbon cycle, although animal farming is on land and aquaculture is in the water. The term "livestock revolution" has been used to describe the rapid expansion of livestock production in developing countries (Delgado et al. 1999). As a consequence of growth in the human population, economy, and urbanization, Asia has the fastest developing livestock sector among the developing countries. (The annual growth rate of meat production over the same time period was 8.4\% in China and 5.7\% in Southeast Asia (Gerber et al. 2005)). Southeast Asia is dominated by monogastric species (such as pigs, laying hens, broilers, and ducks), not only because monogastrics have a better feed conversion ratio

\footnotetext{
${ }^{1}$ Unpublished data from Prof. Chen-Tung. Arthur Chen 2003.
} 
Fig. 4. (a) Cumulative population on the river watershed (million inhabitants) and DOC $\left(\mu \mathrm{mol} \mathrm{L}^{-1}\right)$ concentration versus distance $(\mathrm{km})$ from Pearl River mouth; $(b) \mathrm{DOC}\left(\mu \mathrm{mol} \mathrm{L}^{-1}\right)$ concentration versus cumulative population on the river watershed (million inhabitants).

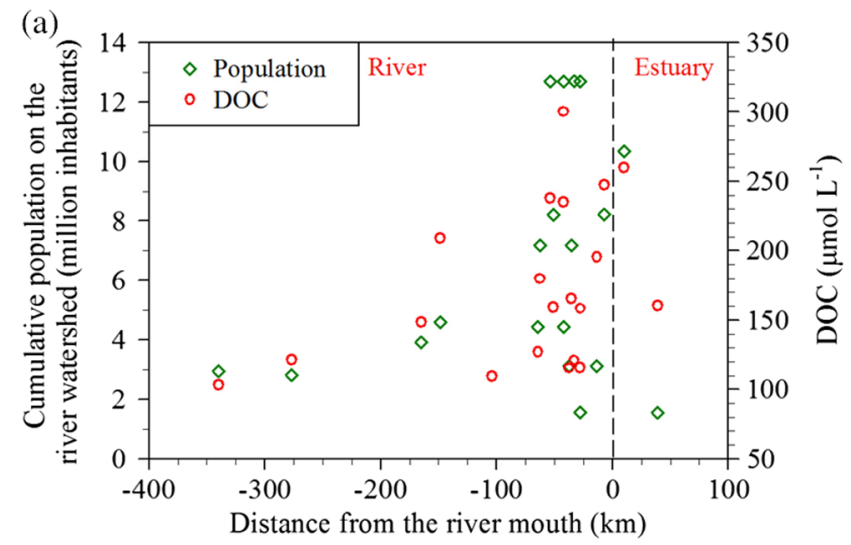

(b)

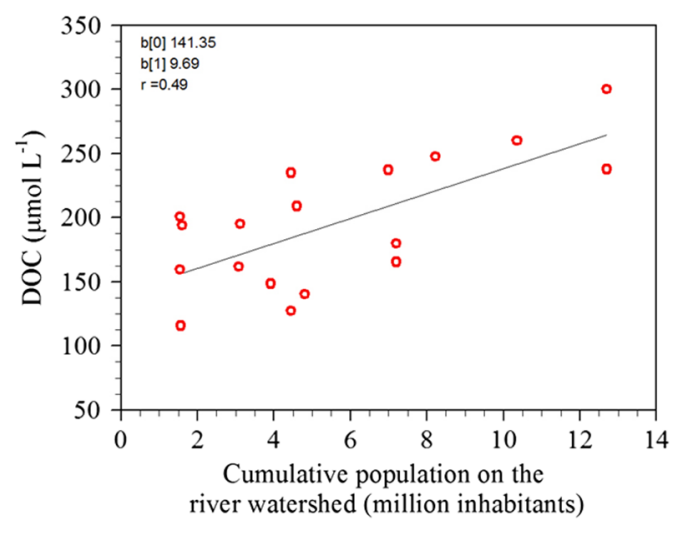

than ruminants (such as cattle, sheep, and goats), but also because of the preferences of its consumers. (Most Asians view cattle as scared or workers in farm but not for meat consumption so eating beef is against the culture and the religion in most Asian countries.)

According to Gerber et al. (2005), high densities of pigs and poultry are observed around urban centers, such as Hanoi, Bangkok, Manila, and Guangzhou, and in highly populated areas, such as the southeastern Chinese coast, because of the demand on meat consumption in the urban centers. However, very low pig densities and a strong poultry population are found in Indonesia because this country has the largest Islamic population of any nation.

According to Holm-Nielsen et al. (2009), an average pig in European countries produces 1.84 (wet) ton of manure. Pig manure has a low dry matter content of $6 \%-10 \%$ of which $40.7 \%$ is organic carbon (Moral et al. 2005). China's Guangdong province is near the SCS and had 35319 thousand heads of pig in 2016 (Guangdong agriculture statistics 2016). If the annual average amount of manure per head of pig in Guangdong province is the same as that in European countries, then pig farms in Guangdong province produce about 1.6-2.6 million tons of total organic carbon (TOC) annually. Most Asian cities do not have effective animal farming wastewater treatment systems. In the Philippines, for example, only $10 \%$ of wastewater is treated while in Indonesia the figure is $14 \%$, and in Vietnam, it is $4 \%$ (Asian Development Bank 2011). In many countries, disposal and delivery systems for animal manure from intensive non-ruminant agriculture are not in place, and wastewater 
from livestock production enters streams and coastal waters through discharge, run-off or the overflow from lagoons. The wastewater from pig farms contains a high concentration of organic matter that exceeds the carrying capacity of the environment (González et al. 2008), causing soil and water contamination, emerging health hazards, and increasing GHG emissions.

Coastal aquaculture has been a traditional practice in Southeast Asia for over 500 years. However, significant strides in aquaculture have been made in the last few decades, during which period production has reached a commercial scale through the improvement of fish farming techniques, such as the intensification of farm operations, refinement of hatcheries by controlled breeding, and general improvements in farm management (Chua et al. 1989). The proportion of edible fish that have been produced through aquaculture increased from $10 \%$ of total fish production in Southeast Asia in 1980 to $17 \%$ in 2000, and 27\% in 2006 (Hishamunda et al. 2009). Overfeeding in aquaculture may increase nutrients and organic matter in the water. Eutrophication in the surface water (Gerber et al. 2005) and hypoxia in the intermediate and bottom waters (Lui et al. 2014) may occur as a result of the increased input of organic substances.

\section{(D4) Rapid industrial development and the bio-economy}

Since the early 1960s, the economic development strategies of virtually all the Southeast Asian states, and especially those countries around the SCS, emphasized urban industrialization. This is mostly owing to large inflows of direct foreign investment. Industrialization has involved low value-added manufacturing to higher value-added manufacturing and, more recently, services. Paper and food-processing industries produce a lot of organic waste, which can be discharged into the rivers and coastal waters as sewage.

In 2009, China overtook the United States as the world's leading producer of paper and is now responsible for around one-quarter of the total global production (Bajpai 2016). The pulp and paper industry in Indonesia has also been expanding recently as a result of increasing paper consumption in Asia, and particularly in China. In the newsletter of Indonesia Investments (2014), the Deputy Chairman of the Indonesia Pulp and Paper Association said that "growing pulp and paper consumption in Asia is important for the industry globally as consumption of these products has been declining in North America and Europe, where computers and mobile devices have increasingly succeeded in replacing paper products."

The environmental problems of the pulp and paper industry are high water consumption, wastewater generation, the generation of solid waste, including sludge from wastewater treatment plants (WWTPs), and GHG emissions. The major problem of wastewater is its high organic content equivalent to COD of around $20-110 \mathrm{~kg}$ per ton of air-dried paper (Ince et al. 2011). COD is widely used in wastewater monitoring, and in the design, modeling, and operational analysis of treatment plants (Mittal and Ratra 2000; Kim et al. 2007). Dubber and Gray (2010) found significant linear relationships between COD and TOC content in settled (influent) domestic and municipal wastewater. The study concludes that TOC can be reliably used to evaluate COD $(\mathrm{COD}=49.2+3 \times \mathrm{TOC})$ in influent wastewaters. One ton of air-dried paper can produce as much as $20 \mathrm{~kg}$ of TOC.

The food processing industry is important for the economic development of Southeast Asian nations; the tropical climate and diversity of agricultural products (Ngoc and Schnitzer 2009). Food processing industry has rapidly grown in Southeast Asian countries, and Thailand is one of the world's leading agricultural suppliers, primarily owing to its well-developed food processing sector (GAIN 2014). Thailand's growing agriculture sector currently accounts for more than $10 \%$ of the country's GDP, and employs nearly $40 \%$ of its labor force (GAIN 2014). The demand for processed foods and ready-to-eat meals has increased owing to rapid urbanization and a growing number of women in the workforce. 
Waste and wastewater from the food processing industry contain large amounts of organic matter. For example, when one ton of citrus is processed, approximately $300 \mathrm{~kg}$ of citrus waste is generated; all of it is organic waste (Ngoc and Schnitzer 2009). Packaging creates additional waste.

\section{(D5) Agricultural intensification}

The dominant form of agriculture in the countries around the SCS is wet rice cultivation. Farmers usually flood rice fields throughout the growing season, causing $\mathrm{CH}_{4}$ to be produced by microbes in the submerged soil when organic matter decays. Flooded rice paddy fields are responsible for approximately $10 \%$ of global anthropogenic $\mathrm{CH}_{4}$ emission (Kirschke et al. 2013). $\mathrm{CH}_{4}$ emissions from rice paddies in tropical Asian countries account for $90 \%$ of annual $\mathrm{CH}_{4}$ emissions from rice paddies globally (Yan et al. 2009; IPCC 2013).

According to the data from Food and Agriculture Organization of the United Nations (FAO 2011), the area of rice cultivation in Asia increased from 107 million ha in 1961 to 137 million ha in 2010 due to population growth. Although the area of rice cultivation only increased $28 \%$, rice production increased significantly from 200 million tons in 1961 to 600 million tons in 2010. The rice yield was 1.86 tons per ha in 1961 and 4.45 tons per ha in 2010 due to agrochemical usage and improvement in agricultural technology. Although the main crop (rice) species has not changed much, the use of agrochemicals has intensified agriculture in the last few decades.

Most of the $\mathrm{CH}_{4}$ emissions from rice fields involve bubble ebullition from the soil, which account for $35 \%-62 \%$ of all such $\mathrm{CH}_{4}$ emissions (Komiya et al. 2015). The decomposition of organic carbon in rice paddy soil has two steps: organic carbon is initially decomposed into floodwater or DOC, which is then converted into $\mathrm{CO}_{2}$ and $\mathrm{CH}_{4}$ (Cheng et al. 2001). Floodwater with a high organic carbon concentration and surplus agrochemicals can flow into rivers, groundwater or coastal waters, increasing $\mathrm{CH}_{4}$ concentrations in, and emissions from, those rivers and coastal waters. As the countries that surround the SCS are dominated by wet rice cultivation, which is an important anthropogenic $\mathrm{CH}_{4}$ source, agriculture intensification in those countries increases the $\mathrm{CH}_{4}$ concentration in, and emission from, the SCS.

\subsection{Resulting pressure on the environment}

Economic drivers and human activities cause environmental pressures, which are (P1) increased organic carbon in rivers and the SCS, (P2) increased COD of the water that is discharged into the SCS, and (P3) increased $\mathrm{CH}_{4}$ concentrations in rivers and the SCS.

\section{(P1) Increased organic carbon in rivers and the SCS}

Most riverine organic carbon derives from living and dead biota. Other sources include geological features, pollution, and groundwater (Raymond et al. 2004; Chen et al. 2012). Changes in land use have also caused the release of organic carbon that had been stored in the soil. Soil is the largest terrestrial pool of organic carbon, which is at least three times larger than the pool of atmospheric $\mathrm{CO}_{2}$ (Jobbágy and Jackson 2000; Amundson 2001). Conversion from forest to farmland, grassland or building significantly decreases soil carbon stocks (Deng et al. 2016).

The countries that surround the SCS have experienced explosive economic growth over the last two decades, resulting in rapid industrialization, urbanization, and a substantial increase in population. Intense anthropogenic activities on land have generated large amounts of organic pollutants that may be transported into the SCS (Ni et al. 2008). In the urban areas in these surrounding countries, people generate $0.49 \mathrm{~kg}$ MSW from per person daily (Cambodia) to $1.99 \mathrm{~kg}$ per person daily (Hong Kong) (Table 1) and about $50 \%$ of the 
Fig. 5. Annual $\mathrm{COD}_{\mathrm{cr}}$ input $\left(1000\right.$ ton $\left.\mathrm{yr}^{-1}\right)$ of Pearl River.

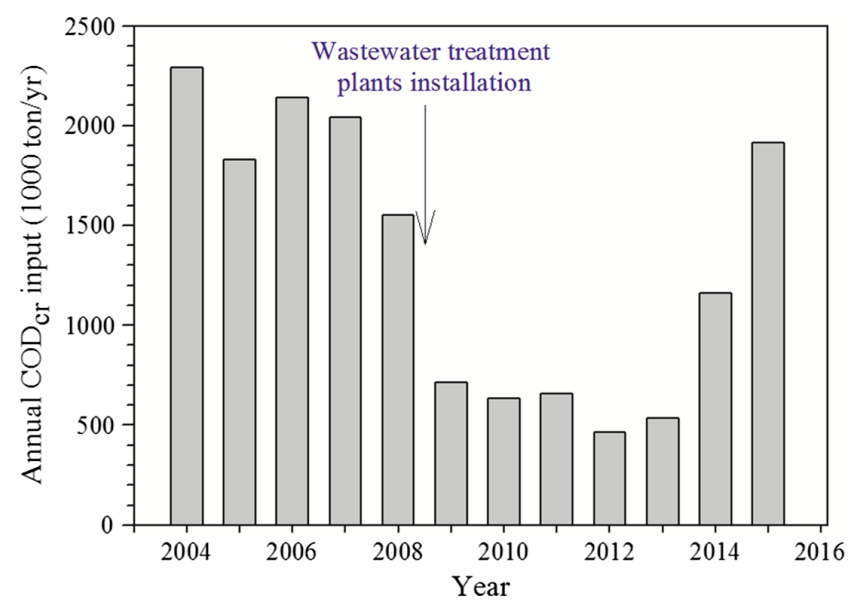

MSW is organic matter (The World Bank 2012). If only $1 \%$ of the organic matter from the MSW is transported by the rivers and into the coastal areas, then the SCS receives around 1700 tons of organic matter daily.

\section{(P2) Increased COD of the water that is discharged into the SCS}

Based on data from the Bulletin of the Marine Environmental Status of China for the years 2004-2015 (National Oceanic Administration 2012), Fig. 5 shows the annual amount of the $\mathrm{COD}_{\mathrm{cr}}$ in the Pearl River. The COD $\mathrm{Cr}_{\mathrm{cr}}$ of the Pearl River increased from 2004 to 2008. China-Second Guangdong PRD Urban Environment Project, 2007-2013, had the objective of reducing water pollution in the Pearl River system that originated from Foshan and Jiangmen municipalities (The World Bank 2015). The Dongguan municipal government spent more than 10 billion yuan (US\$ 1.5 billion) on building 35 WWTPs in 2007. Some of the WWTPs became operational in February 2008, and water quality in the canal since improved to Grade IV from Grade V (Chinadialogue 2011). Dongguan, Foshan, and Jiangmen (Fig. 6) are three of the most populous municipalities in the PRD, and account for about one third of the population there. Also, the PRD is one of the fastest growing economic areas in China.

Since the aforementioned WWTPs became operational in 2008 , the $\mathrm{COD}_{\mathrm{cr}}$ input in the Pearl River has decreased (Fig. 5). The improvement has been supported by the economic slowdown that forced some factories to close down, reducing pollution (and population, since fewer jobs were available for migrant workers). However, from 2013, a rebounding economy and the return of the migrant workers increased the annual input of $\mathrm{COD}_{\mathrm{cr}}$ in the Pearl River. Moreover, the industrial structure in the PRD changed from 2010 to 2013. Most new factories are built in suburbs or other municipalities in the PRD, where the land is cheaper but WWTPs are absent, so the annual input of $\mathrm{COD}_{\mathrm{cr}}$ in the Pearl River has risen since 2014.

The wastewater that is generated by inhabitants is often expressed using the unit Population Equivalent (PE).

$1 \mathrm{PE}=60 \mathrm{~g} \mathrm{BOD} / \mathrm{d}=126 \mathrm{~g} \mathrm{COD} / \mathrm{d}$

This formula is based on a fixed value of generating COD per day per person. However, the actual contribution to the environment of a person who lives in a sewer catchment, 
Fig. 6. Map of sampling stations in PRD and estuary.

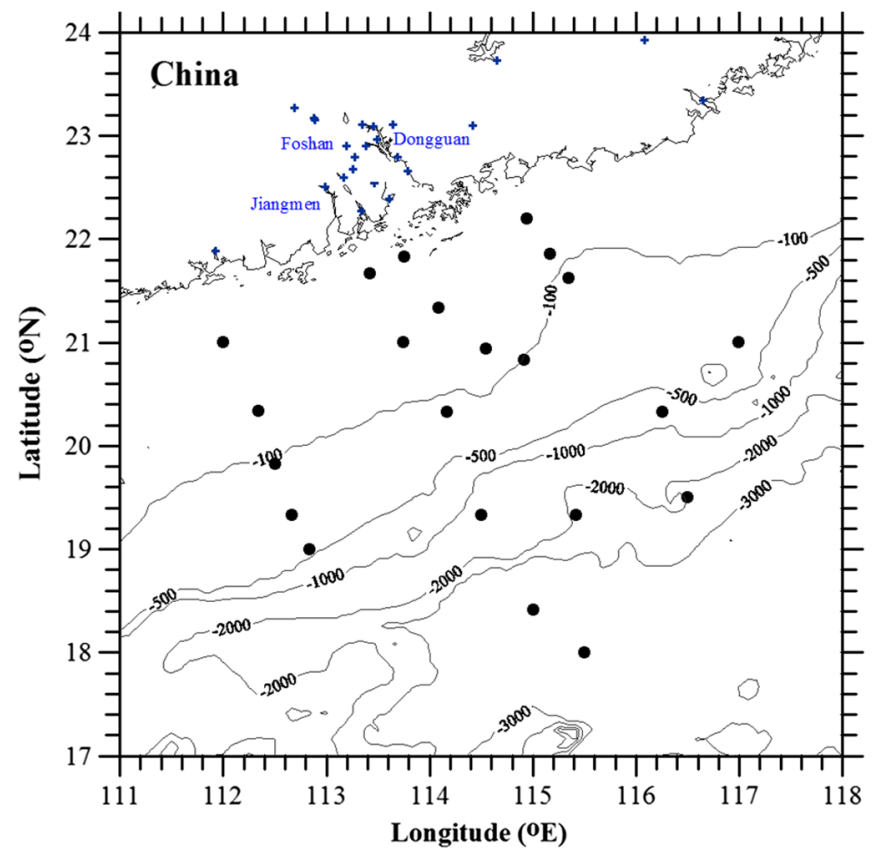

the so-called person load, can vary considerably (Henze et al. 2001). The reasons for variation can be work outside the catchment, socio-economic factors, lifestyle, type of household, and others. Because the coastal sub-regions of the SCS are home to 270 million people (Pernetta and Bewers 2013), the wastewater from its inhabitants contains about 34000 tons COD/day. If the wastewater from the coastal sub-regions were discharged into the SCS without any treatment, then the SCS would annually receive discharged water that had 12.4 million tons of COD.

\section{(P3) Increased $\mathrm{CH}_{4}$ concentrations in rivers and the SCS}

$\mathrm{CH}_{4}$ in marine areas is biologically produced in seawater, has diffused from organic-rich anaerobic sediment (Borges et al. 2017), and (or) is contained in inputs of $\mathrm{CH}_{4}$-rich freshwater (Scranton and McShane 1991). Human activities have increased organic carbon and decreased dissolved oxygen (DO) concentrations in the aquatic systems (Diaz and Rosenberg 2008). As increasing amounts of organic matter are input from the land and eutrophication-induced hypoxia in the aquatic environment increases, $\mathrm{CH}_{4}$ concentrations in the rivers and the coastal waters increase, increasing $\mathrm{CH}_{4}$ emissions to the atmosphere (Bange 2006; Naqvi et al. 2010; Borges et al. 2017).

Chen et al. (2008) sampled surface waters from the tributaries of the Pearl River and its estuary in September 2003 (Fig. 6). Degradation of organic carbon in freshwater and estuarine environments is partially mediated by anaerobic processes, including methanogenesis, which leads to the production of $\mathrm{CH}_{4}$ and high $\mathrm{CH}_{4}$ emissions from surface waters to the atmosphere, in particular in sub-tropical and tropical environments (Borges and Abril 2011; Borges et al. 2015). High concentrations of $\mathrm{CH}_{4}$ were found to be present in the Pearl River; after the river entered the SCS, mixing with the open ocean water, $\mathrm{CH}_{4}$ concentrations decreased rapidly and DO concentrations increased (Fig. 7). 
Fig. 7. $\log \mathrm{CH}_{4}\left(\mathrm{nmol} \mathrm{L}^{-1}\right)$ and $\mathrm{DO}\left(\mu \mathrm{mol} \mathrm{L}{ }^{-1}\right)$ concentrations versus distance $(\mathrm{km})$ from Pearl River mouth.

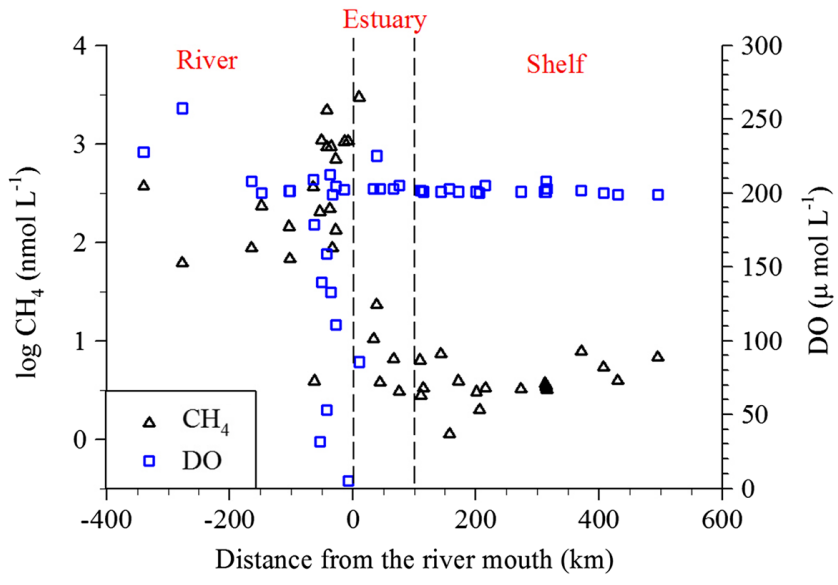

\subsection{STATE of the environment of the SCS}

This section analyzes how the environmental state of the SCS has changed, with particular consideration of (S1) increased $\mathrm{CH}_{4}$ concentrations in the SCS; (S2) reduced DO concentrations in the SCS, possibly causing coastal hypoxia and increasing $\mathrm{CH}_{4}$ generation; (S3) increased temperature as a result of the greenhouse effect of $\mathrm{CH}_{4}$; and (S4) destabilized seabed (high concentrations of interstitial gas in sediments).

\section{(S1) Increased $\mathrm{CH}_{4}$ concentrations in the SCS}

The northeastern SCS is connected to the western Philippine Sea (wPS; Fig. 3) via the Luzon Strait, which has the deepest sill that connects the SCS with any adjacent body of water. Because the Luzon Strait is $2200 \mathrm{~m}$ deep, surface and intermediate waters are exchanged freely between the SCS and the wPS; the waters deeper than $2200 \mathrm{~m}$ in the SCS are relatively homogeneous, with hydrochemical properties similar to the water at $2200 \mathrm{~m}$ in the wPS (Chen et al. 2006a). Only recently has $\mathrm{CH}_{4}$ in the SCS been studied and few historical $\mathrm{CH}_{4}$ data are available. Because the majority of the water in the SCS originates from the wPS (Chao et al. 1996; Chen et al. 2001), we can calculate the amount of increasing $\mathrm{CH}_{4}$ concentrations by comparing the $\mathrm{CH}_{4}$ concentrations in the SCS with those in the wPS.

Figure 8 shows the average $\mathrm{CH}_{4}$ concentrations at depths at intervals of $100 \mathrm{~m}$ in the SCS and in the wPS. In the surface water layer $(0-350 \mathrm{~m})$, the average $\mathrm{CH}_{4}$ concentrations in the SCS and in the wPS were $4.8 \pm 5.7(n=416)$ and $3.7 \pm 1.3(n=70) \mathrm{nmol} \mathrm{L}^{-1}$, respectively; in the intermediate water layer (350-1350 m), the average $\mathrm{CH}_{4}$ concentrations in the SCS and in the wPS were $3.4 \pm 3.0(n=155)$ and $2.2 \pm 1.1(n=68) \mathrm{nmol} \mathrm{L}^{-1}$; in the deep water layer $(1350-2200 \mathrm{~m})$, they were $1.9 \pm 1.7(n=48)$ and $1.5 \pm 0.6(n=29) \mathrm{nmol} \mathrm{L}^{-1}$ (Tseng et al. 2017). As a result, the $\mathrm{CH}_{4}$ concentration in the SCS is higher than that in the wPS throughout the water column. The surface water of the SCS is strongly influenced by terrestrial input and has a $\mathrm{CH}_{4}$ concentration that is about 20\% higher than that of the wPS, presumably due to human activities.

(S2) Reduced DO concentrations in the SCS, possibly causing coastal hypoxia and increasing $\mathrm{CH}_{4}$ generation

Eutrophication and related hypoxia adversely affect marine ecosystems (Newton et al. 2003; Howarth 2008; Rabalais et al. 2010; Lui and Chen 2012). As the stratification of seawater increases under global warming and nutrient fluxes from terrestrial sources also 
Fig. 8. Vertical distributions of average $\mathrm{CH}_{4}$ concentration $\left(\mathrm{nmol} \mathrm{L}{ }^{-1}\right)$ every $100 \mathrm{~m}$ in SCS and wPS above $2300 \mathrm{~m}$.

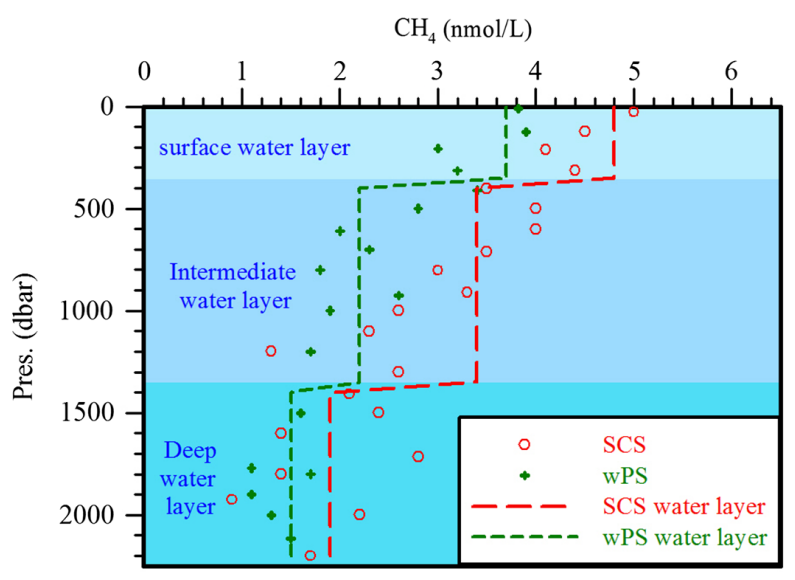

increase (Chen 2008; Diaz and Rosenberg 2008; Rabalais et al. 2010), more coastal ecosystems reportedly exhibit hypoxia.

Tseng et al. (2016) reveals that the DO concentrations in the SCS are generally lower than those in the wPS at depths up to $800 \mathrm{~m}$. Lui and Chen (2012) found that DO\% was low (sometimes hypoxia) in the bottom water, especially in the summer. The weather systems in the SCS region are dominated by the Asian monsoon and approximately $80 \%$ of annual rain falls in the rainy season between May and October (Debenay and Luan 2006). The nutrient-enriched freshwater enhances the local primary production in the surface water and the organic matter from the surface water then decomposes in the bottom water or on the continental shelf (Lui and Chen 2012; Lui et al. 2014). In addition, summer stratification reduces the ventilation between the subsurface water and the atmosphere. As a result, the DO concentration is low or hypoxia occurs in the intermediate or bottom waters of the continental shelf, during the wet season. Because of increasing organic matter from land and the hypoxia in the intermediate or bottom waters of the continental shelf, $\mathrm{CH}_{4}$ generation may have occurred and it may increase the coastal $\mathrm{CH}_{4}$ emissions.

(S3) Increased temperature as a result of the greenhouse effect of $\mathrm{CH}_{4}$

The sea-to-air flux of $\mathrm{CH}_{4}$ in the wet season (May to October) in the SCS is $8.6 \pm$ $6.4 \mu \mathrm{mol} \mathrm{m} \mathrm{m}^{-2} \mathrm{~d}^{-1}$ (Tseng et al. 2017). The $\mathrm{GWP}_{20}$ of $\mathrm{CH}_{4}$ is 86 , so the flux of $\mathrm{CH}_{4}$ is about $740 \mu \mathrm{mol} \mathrm{m}{ }^{-2} \mathrm{~d}^{-1}$ in $\mathrm{CO}_{2}$ equivalents. This value is similar to the sea-to-air flux of $\mathrm{CO}_{2}$ $\left(631.2 \pm 163.2 \mu \mathrm{mol} \mathrm{m}^{-2} \mathrm{~d}^{-1}\right.$, Chou et al. 2005; $729.6 \mu \mathrm{mol} \mathrm{m}^{-2} \mathrm{~d}^{-1}$, Chen et al. 2006b) in the wet season. $\mathrm{CH}_{4}$ emissions in the SCS currently cause similar warming as $\mathrm{CO}_{2}$ in the wet season. However, as $\mathrm{CH}_{4}$ emissions increase, the greenhouse effect of $\mathrm{CH}_{4}$ will significantly increase, as well as the temperature.

\section{(S4) Destabilized seabed (high concentrations of interstitial gas in sediments)}

Beneath the SCS seabed may be huge oil, gas, and gas hydrate reserves (Morton and Blackmore 2001). The southern SCS near Brunei has abundant petroleum and gas (OPL 2000). Recent research has revealed $\mathrm{CH}_{4}$ seepage in the northeastern part of the SCS (Boetius et al. 2000; Boetius and Suess 2004), with buildups of authigenic carbonate, named the Jiulong Methane Reef (Suess 2005; Han et al. 2008). $\mathrm{CH}_{4}$ gas hydrates have been detected in the northern SCS. Seismic profiles of these areas demonstrate that bottom simulating reflectors are widespread under the sea floor, possibly indicative of gassy sediments 
(Wu et al. 2005, 2009). In addition, geochemical evidence suggests the presence of submarine gas hydrate deposits around these areas (Chen et al. 2005; Su et al. 2005). High $\mathrm{CH}_{4}$ concentrations in the seawater have been found (Chen and Tseng 2006; Zhou et al. 2009; Tseng et al. 2017) and are possibly caused by the seepage of $\mathrm{CH}_{4}$ from seafloor sediments. Warming seawater reduces the solubility of $\mathrm{CH}_{4}$ and may increase the amount of $\mathrm{CH}_{4}$ gas that is released from gassy sediments in it, potentially destabilizing the seabed.

\subsection{IMPACT on human welfare}

As economic drivers and human activities cause environmental pressure, the state of the environment is changing. This section concerns the possible changes in human welfare as a result of changes in the environment. Possible future effects are as follows. (I1) Reduced catches of commercial species of benthos and fish; (I2) rising sea levels and storminess as a result of increased surface seawater temperature, increasing the vulnerability of coastal populations; (I3) destabilization of seabed, causing blowout or collapse of offshore structures; (I4) future energy prospecting for gas hydrate extraction, potentially creating jobs and increasing energy security; and (I5) escalation of geopolitical tensions because of valuable maritime resources.

\section{(I1) Reduced catch of commercial species of benthos and fish}

Based on Intergovernmental Panel on Climate Change (IPCC) scenarios (IPCC 2013), as the ocean warms, some marine species may find that areas that were previously suitable for their survival have become unfavorable, so many populations of marine fish and invertebrates shift following changes in ocean conditions (Sunday et al. 2011). Studies of the potential effects of climate change on global fisheries have predicted a large-scale redistribution of catch potential (Cheung et al. 2010; Blanchard et al. 2012) and increased vulnerability of many coastal fisheries, particularly in the tropics (Allison et al. 2009). Populations of marine fish and invertebrates tend to be shifting to higher latitudes and deeper waters (Cheung et al. 2013). The overall abundance of species with limited dispersal potential or a narrow range of temperature tolerance, such as in semi-enclosed seas and the tropics, will decrease (Portner and Knust 2007; Ben Rais Lasram et al. 2010). The SCS is a semi-enclosed marginal sea and a region where the climate is tropical. Consequently, catches of commercial species of benthos and fish in the SCS are likely to shrink.

A report based on a global database on marine fisheries and ecosystems (Sea Around Us 2007) claims that approximately 6 million tons of fish were caught in the SCS in 2004, with a value of US\$ 6 billion. The Wall Street Journal reported that fish stocks in the SCS have fallen by $70 \%-95 \%$ from 1950 s levels, according to research done at the University of British Columbia. Not only may coastal hypoxia, caused by an increasing input of organic matter from land, kill fish, but also increasing seawater temperature owing to global warming will reduce the size of catches of commercial benthos and fish in the SCS.

(I2) Rising sea levels and storminess as a result of increased surface seawater temperature, increasing vulnerability of coastal populations

Surface temperature is projected to rise over the 21st century in all assessed GHG emission scenarios (IPCC 2014). According to the fifth assessment report (AR5) of the IPCC, the global mean sea level is very likely to continue to rise during the 21st century, owing to an increase in ocean warming (thermal expansion) and a loss of mass from glaciers and ice sheets. Additionally, climate model projections through the 21st century show an increase in total monsoon rainfall. Heat waves are very likely to occur more often and last longer, and extreme precipitation events will become more intense and frequent in many regions (IPCC 2014). Moreover, as typhoons form over warm water, the frequency of the 
most intense storms and typhoons is likely to increase. As sea level rises and storminess increases, coastal populations will become more vulnerable.

(I3) Destabilization of seabed, causing blowout or collapse of offshore structures

Submarine landslides are especially prevalent in river deltas, because of the high rate of sediment delivery, and the presence of submarine canyons (Archer 2007). In addition, warming may trigger the melting of gas hydrate deposits, provoking landslides (Kvenvolden 1999; Driscoll et al. 2000; Vogt and Jung 2002). As gas hydrates are very sensitive to changes in temperature and pressure (Dickens and Quinby-Hunt 1994; Brewer et al. 1997), global warming may destabilize gas hydrates (Archer 2007; Kennedy et al. 2008; Archer et al. 2009; O'Connor et al. 2010) and increase the flux of $\mathrm{CH}_{4}$ to the atmosphere. The instability of gas hydrates may destabilize the seabed, trigger submarine landslides or cause submarine earthquakes. The primary hazards that are associated with submarine landslides and submarine earthquakes are the direct destruction of infrastructure and submarine cables, and the occurrence of tsunamis.

(I4) Future energy prospecting for gas hydrate extraction, potentially creating jobs and increasing energy security

Gas hydrates are considered to be an important new resource (Chen and Tseng 2006). Exploring and extracting gas hydrates may create jobs and increase energy security. For example, Oil and Gas UK (2018) has shown that this industry in the North Sea employed an estimated 41700 people in 2014, and the number of jobs that rely on the industry including taxi drivers, hotel staff, and caterers - is about 453800 . However, the use of sonar for prospection may disrupt other marine activities, such as fishing. The SCS is one of the world's most important fishing grounds, employing more than 3.7 million people and generating billions of dollars every year (Pauly et al. 2014). Exploring and extracting activities affect the marine ecosystem and the fisheries on which 3.7 million people rely. Furthermore, gas hydrates are very sensitive to temperature and pressure, and they expand very quickly in response to temperature and (or) pressure changes. One litre of $\mathrm{CH}_{4}$ gas hydrates under standard conditions $\left(1 \mathrm{~atm}, 0^{\circ} \mathrm{C}\right)$ can become $168 \mathrm{~L}^{\circ} \mathrm{CH}_{4}$ gas, so extracting gas hydrates has a high risk of explosion and may cause a serious hazard. Therefore, risk assessments must be conducted and counter measures taken before extraction, especially in warm seas.

(I5) Escalation of geopolitical tensions because of valuable maritime resources

The SCS is one of the most contested maritime areas of the world. Competing territorial claims over the SCS and its resources are numerous with the most contentious revolving around the Spratly and Paracel Islands (Chen 2013). Geopolitical tensions escalate because of valuable maritime resources. According to Hill et al. (1991), the northern, western, and southern regions of the SCS contain between 10 and 14 billion barrels of oil. However, most of the sea areas and island groups are disputed. Climate change may worsen regional tensions and natural disasters, increase the number of climate refugees and reduce food security as a result of reduced fish catches and crop production.

\section{Discussion and recommendations}

\subsection{Societal response and management recommendations from DPSIR}

Previous sections analyzed the economic drivers and human activities that have caused environmental pressure, changed the state of the environment, and will potentially impact human welfare. This section discusses societal responses and management recommendations. Those responses are as follows: (R1) education and raising awareness, (R2) research into the exploitation of $\mathrm{CH}_{4}$ gas hydrates, (R3) the development of the circular economy, 
(R4) construction of infrastructure (building WWTPs), (R5) technological development (recycling reusable items and reducing waste), (R6) application of agricultural technology (new rice cultivation methods), (R7) optimization of agricultural practices (stop using excess agrochemicals and start smart fertilizer application), and (R8) governance measures.

\section{(R1) Education and raising awareness}

Education affects our future. "Anthropogenic GHG emissions are mainly driven by population size, economic activity, lifestyle, energy use, land-use patterns, technology and climate policy" (IPCC 2014). Changing of human behaviors and lifestyles may slow down climate change, provide more opportunities for human beings, as well as allowing other life forms, to adapt to the changing climate. Education not only raises people's awareness but also helps them make better choices concerning the environment and themselves. For example, a balanced diet should contain only $20 \%$ animal products (or protein alternatives); such a diet is good not only for health but also for the environment (Liu and Savenije 2008). Furthermore, consuming local products supports local business and reduces transport distances and carbon footprints.

People make choices about their economic activities, lifestyle, energy use, and land-use patterns. If more people were informed, willing to change, and able to make better choices, then the greenhouse effect could be more easily mitigated and climate change more easily slowed down. Education can help to achieve these goals.

(R2) Research into the exploitation of $\mathrm{CH}_{4}$ gas hydrates

Gas hydrates are stable at low temperature and high pressure, which prevail in oceanic sediments along continental margins, where water depths are $>500 \mathrm{~m}$ (Sha et al. 2015). This minimum stability depth is less in the high-latitude oceans, and about $200 \mathrm{~m}$ in the Arctic Ocean, because the upper water column is colder (Archer 2007). Although gas hydrates have been considered to be a potential source of energy, research into the extraction of $\mathrm{CH}_{4}$ gas hydrates has begun only recently. In Canada, Norway, Japan, and Alaska, where the latitude is high, the gas hydrate stability depth is smaller. The SCS is located in a tropical area where the seawater is warm and the gas hydrate stability depth is large so extraction is even more complicated. $\mathrm{CH}_{4}$ gas hydrates are released faster in warm seas than in cold waters so extraction of $\mathrm{CH}_{4}$ gas hydrates in the SCS is more difficult and dangerous than it is at high latitudes. Moreover, when the temperature increases and (or) pressure decreases, the volume of gas hydrates expands rapidly (changes from solid phase to gas phase) with a high probability of explosion. Thus, more research on the exploitation of $\mathrm{CH}_{4}$ gas hydrates, especially in warm seas, is needed.

The SCS is one of the most contested maritime areas in the world. Competing territorial claims over the SCS, and especially over the Spratly and Paracel Islands, exist (Chen 2013). While countries are trying to consolidate their claims to sovereignty, they still share a desire to sustain a peaceful regional environment to promote prosperous economic development (Chen 2013). Once the methods of extracting $\mathrm{CH}_{4}$ gas hydrates have been resolved, they will be a valuable natural resource. Competition to extract $\mathrm{CH}_{4}$ gas hydrates may escalate geopolitical tensions around the SCS if no internationally agreed upon governance measures are in place.

\section{(R3) The development of the circular economy}

A circular economy is an industrial economy that is restorative and regenerative by design. Its aim is to promote greater resource productivity, reduce waste, and avoid pollution (Tukker 2015). Recently, the concept of the circular economy has gained increased attention with a focus on transforming waste into resources while bridging production and consumption activities (Witjesa and Lozanoa 2016). Yong (2007) and Yuan et al. (2006) 
indicated that such a circular economy has to be achieved by closing loops of different types and levels of recovery of valuable resources between parties in society. For instance, the food processing industry produces a lot of organic waste. The discharging of those organic wastes into rivers, lakes or coastal waters without treatment causes eutrophication and hypoxia in the aquatic system and increases GHG emissions. On the other hand, the processing and re-production of organic waste as a fertilizer reduces the amount of waste that is generated by the food processing industry with the added benefit of using natural fertilizer instead of chemicals.

Another example of circular economy is the generation of electricity using the $\mathrm{CH}_{4}$ gas from manure in pig farms. Anaerobic digestion has been applied to treat swine waste (Montalvo 1995: Boopathy 1998; Hill and Bolte 2000). The process converts organic waste into biogas (which is a gas mixture of approximately $70 \% \mathrm{CH}_{4}$ and $30 \% \mathrm{CO}_{2}$ ) that can be used to generate heat and (or) power. According to $\mathrm{Su}$ et al. (2003), the emission of $\mathrm{CH}_{4}$ from an anaerobic swine wastewater treatment system in Taiwan is $0.768 \mathrm{~kg}$ per head per year and about 5756 tons annually. The average calorific value of biogas is about $6 \mathrm{kWh} \mathrm{m}^{-3}$, which corresponds to about half a litre of diesel fuel (FNR 2009). The $\mathrm{CH}_{4}$ gas that is produced by a swine waste treatment system in Taiwan can generate up to about 52 million $\mathrm{kWh} \mathrm{m}^{-3}$ of energy annually, which corresponds to 26 million $\mathrm{L}$ of diesel fuel. (The density of $\mathrm{CH}_{4}$ is $0.668 \mathrm{~kg} \mathrm{~m}^{-3}$ at $20^{\circ} \mathrm{C}$.) Based on the price of diesel oil in Taiwan $(1 \mathrm{~L}$ of diesel oil cost around NT\$ 22.2 in March 2017), the total economic value of the $\mathrm{CH}_{4}$ gas from the swine waste treatment system in Taiwan is approximately NT\$ 577 million (US\$ 19 million, based on the exchange rate in March 2017).

(R4) Construction of infrastructure: building WWTPs

One of the most common forms of pollution control is wastewater treatment. Sewers collect wastewater from households, businesses, and many industries, and then deliver it to plants for treatment. Currently, most WWTPs provide a minimum of secondary treatment (EPA 2004; EC 2013). After the primary and secondary treatments have been performed in the WWTPs, $90 \%$ of the organic matter in the wastewater can be removed (EPA 2004). Because most of the pollutants and organic matter is absent from the wastewater beyond the WWTPs, the reclaimed water can be reused or discharged into streams or coastal waters. Building WWTPs not only reduces the amount of pollutants and organic matter in rivers and coastal waters, but also increases their oxygen levels by reducing the COD (Fig. 5). Reducing the amount of organic matter and increasing the oxygen levels in rivers and coastal waters can reduce their $\mathrm{CH}_{4}$ emissions. The $\mathrm{CH}_{4}$ that is produced by the WWTPs can also be utilized as a form of energy (see R3 above).

(R5) Technological development: recycling reusable items and reducing waste

Recycling and reusing food waste and agricultural waste, such as rice straw, can reduce $\mathrm{CH}_{4}$ emissions. In factories, recycling reusable items and material reclamation reduce waste. Environmentally friendly designs and new technology not only reduce the impact of industry on the environment, but also save on manufacturing costs.

The pulp and paper industry has found many ways to re-use their waste. For example, black liquor, a by-product of pulp production, is used as a fuel in a recovery boiler that can produce steam and electricity. Paper sludge, which contains a large amount of organic matter, can be recycled into a reusable product, such as glass aggregate, which is then used for various construction and industrial purposes (Holmen and its World 2009). Sludge from de-inking can be used as a fuel and as a binding agent in the production of building blocks (Holmen and its World 2009). Recycling used chopsticks and newspapers as paper pulp to make new paper not only reduces waste but also produces useful products. 
(R6) Application of agricultural technology: new rice cultivation methods

Rice cultivation is one of the main anthropogenic sources of atmospheric $\mathrm{CH}_{4}$ and wetland rice agriculture accounts for about $10 \%$ of global anthropogenic $\mathrm{CH}_{4}$ emission (Kirschke et al. 2013). Therefore, many studies on reducing $\mathrm{CH}_{4}$ emissions from rice paddies have been published. With further research and the introduction of new rice cultivation methods, $\mathrm{CH}_{4}$ emissions from the rice paddies and $\mathrm{CH}_{4}$ concentrations in the water with which they are flooded can be reduced, reducing the flux of $\mathrm{CH}_{4}$ from the flood water into rivers and the SCS.

Research has shown that installing single or multiple drainage in continuously flooded rice fields can reduce the average $\mathrm{CH}_{4}$ fluxes from rice fields by about 52\% to 60\% (Cai et al. 2003; Yan et al. 2005; Yan et al. 2009). Further research indicates that using slag-type silicate fertilizer, which contains a large amount of active iron oxide, suppresses the production of $\mathrm{CH}_{4}$ and sustains rice productivity (Ali et al. 2008). Using rice straw off-season wherever and whenever possible further reduces $\mathrm{CH}_{4}$ emissions (Yan et al. 2009). According to IPCC (2013), the global $\mathrm{CH}_{4}$ emission from rice fields is around 36 (33-40) Tg annually. New rice cultivation methods could reduce global $\mathrm{CH}_{4}$ emission from rice fields by $19-22 \mathrm{Tg}$ annually, based on the $52 \%$ to $60 \%$ flux reduction (Cai et al. 2003; Yan et al. 2005; Yan et al. 2009).

\section{(R7) Optimization of agricultural practices: stop using excess agrochemicals and start smart fertilizer application}

Agrochemicals provide many benefits, such as increased yields of plant and animal crops, and less spoilage during storage (Aktar et al. 2009). Genetically improved crop species and agrochemical applications have significantly increased crop yields (Warren 1998). Increasing food supply and improving food security for the rapidly increasing global population. However, excessive use of agrochemicals can lead to contamination of soil and groundwater (Aktar et al. 2009). In addition, the run-off of agricultural fertilizer into streams, lakes, and other surface waters can cause eutrophication (Newton et al. 2003). The ecological effects of eutrophication can include low oxygen content or hypoxia in water, increased $\mathrm{CH}_{4}$ concentrations and emissions, high mortality of fish, excessive growth of harmful algae, and poor tasting drinking water.

The timing of fertilizer application is important and significantly affects crop yields. Smart fertilizer use requires the establishment of a soil management plan that will create a more sustainable soil system. Using fertilizer at the correct time and in the correct amount or placing fertilizer at the proper depth can increase crop yields, reduce nutrient losses, increase the efficiency of nutrient use and prevent damage to the environment (Krans 2015). Smart fertilizer application also reduces the wasting of fertilizer, water usage, and cost.

Reducing the excessive use of agrochemicals through smart fertilizer application and environmentally friendly methods can maintain the benefits of the use of agrochemicals, such as high crop yields, while reducing water usage and costs. Thus, agricultural best practice could substantially reduce $\mathrm{CH}_{4}$ concentrations and emissions from rivers, lakes, and coastal waters.

\section{(R8) Governance measures}

Ostrom (2009) emphasized the importance of good governance at all levels, and the community-based management of common pool resources, such as $\mathrm{CH}_{4}$ gas hydrates. Here, we discuss governance measures from both national and international perspectives. Top-down management by the governmental authority can support various solutions for the reduction GHG emissions, such as law enforcement, tax shifting, and international cooperation. 


\section{Local-national governance measures}

Local or municipal authorities usually make decisions on building, expanding or improving WWTPs to protect the environment, reduce GHG emissions, improve the quality of water, and treat domestic sewage. National environmental laws can be used to control and reduce the amount of organic matter and nutrient pollution on land and into waters. Implementing environmental policy can improve land-use and urban planning, linking housing to sanitation facilities. Subsidies, taxes and fines may also be used nationally to encourage environmental friendly industries, such as by levying a tax on polluting companies or pollutants on a "polluter pays" basis. For example, the government can levy a tax on chemical fertilizer and allocate the money thus collected to subsidize biogas plants.

Concerted actions of this type by a group of nations, such as the Water Framework Directive in Europe (EEA 2015), can result in significant abatement, such as the concentration of phosphorus in European rivers (EEA 2005).

\section{Regional-international governance measures}

International cooperation, especially in the SCS, is difficult (Chen 2013). Historically, numerous conflicts and disputes have arisen concerning the SCS (Valencia 1995; Catley and Keliat 1997; Kivimaki 2002; Odgaard 2002). Nevertheless, joint scientific progress has been made in the region. For example, a project of the United Nations Environment Programme (UNEP) that was entitled "Reversing environmental degradation trends in the South China Sea and Gulf of Thailand" was implemented from 2002 to 2008 . According to the research that formed part of this project, the socioeconomic impact of environmental deterioration was significant for the newly developed economies of this region (Bewers and Pernetta 2013). This environmental cooperative project provided an opportunity to exchange and share information for environmental protection and a forum in which duly accredited representatives of the participating countries could discuss environmental management of the SCS (Chen 2013). Unfortunately, relations among countries that border the SCS have deteriorated significantly since 2009 . Thus, after this project ended in 2008 , no follow-up actions have been taken and no international cooperative association of the countries around the SCS exists. Regional Seas Conventions, such as HELCOM (Baltic), the Bucharest Convention (Black Sea), and NOWPAP (North West Pacific) can provide a framework for international environmental protection, climate change mitigation, and adaption (Newton et al. 2014). Such participative conventions can also provide an international cooperative platform on which all the countries around the SCS can maintain environmental sustainability, such as by taking concerted actions to reduce the concentrations of organic matter in effluents that lead to $\mathrm{CH}_{4}$ production.

\subsection{Summary: societal response and management recommendations from DPSIR}

A range of societal responses should be implemented across different time scales (from short to long), and spatial scales (local to international) to reduce $\mathrm{CH}_{4}$ emissions in the SCS. The previous section discussed eight societal responses. Table 2 presents the implementation timeframe and relative cost of each response.

Relatively low-cost, immediate, and local management responses include the implementation of the following:

1. education and raising awareness (R1);

2. technological development (recycling reusable items and reducing waste) (R5);

3. optimization of agricultural practices (stop using excess agrochemicals and start smart fertilizer application) (R7); and

4. local governance measures to implement recycling to reduce waste (R8). 
Table 2. Timeframe, relative cost, and governance level involved in implementing societal responses.

\begin{tabular}{|c|c|c|c|c|}
\hline \multicolumn{2}{|c|}{ Societal response } & \multirow{2}{*}{$\begin{array}{l}\text { Timeframe for } \\
\text { implementation }\end{array}$} & \multirow{2}{*}{$\begin{array}{l}\begin{array}{l}\text { Relative cost of } \\
\text { implementation }\end{array} \\
\$\end{array}$} & \multirow{2}{*}{$\begin{array}{l}\text { Governance level } \\
\text { Local }\end{array}$} \\
\hline (R1) & Education and raising awareness & & & \\
\hline (R5) & $\begin{array}{l}\text { Technological development: recycling } \\
\text { reusable items and reducing waste }\end{array}$ & Very short & $\$$ & Local \\
\hline (R7) & $\begin{array}{l}\text { Optimization of agricultural practices: } \\
\text { stop using excess agrochemicals and } \\
\text { start smart fertilizer application }\end{array}$ & Very short & $\$$ & Local \\
\hline (R8) & Local governance measures & Very short & $\$ \$$ & Local \\
\hline (R6) & $\begin{array}{l}\text { Application of agricultural technology: } \\
\text { new rice cultivation methods }\end{array}$ & Short & $\$ \$$ & Local \\
\hline (R8) & National governance measures & Short & $\$ \$ \$$ & National \\
\hline (R4) & $\begin{array}{l}\text { Construction of infrastructure: building } \\
\text { WWTPs }\end{array}$ & Short & $\$ \$$ & Local/National/Regional \\
\hline (R3) & $\begin{array}{l}\text { The development of the circular } \\
\text { economy }\end{array}$ & Medium & $\$ \$$ & $\begin{array}{l}\text { Local/National } \\
\quad \text { Regional/International }\end{array}$ \\
\hline (R2) & $\begin{array}{l}\text { Research into the exploitation of } \mathrm{CH}_{4} \\
\text { gas hydrates }\end{array}$ & Long & $\$ \$ \$ \$ \$$ & Regional/International \\
\hline (R8) & International governance measures & Very long & $\$ \$ \$ \$$ & Regional/International \\
\hline
\end{tabular}

Note: Low cost, $\$$; high cost, $\$ \$ \$ \$$.

Relatively high-cost, long-term management responses that would provide enormous benefits include the following:

1. research into the exploitation of $\mathrm{CH}_{4}$ gas hydrates, (R2); and

2. international governance measures, such as co-management of the SCS (R8).

\subsection{Future study}

Anthropogenic activities have increased GHG emissions since the industrial era and human activities have also increased the input of organic matter into rivers and coastal areas. Facing human-induced climate change and human-influenced coastal environments, more social-environmental research is needed. Additionally, in dealing with the complex issues of reducing GHG emissions, many interrelated factors exist, such as cost, level of technology development, and expenditures on research and development. To mitigate climate change, many aspects must be considered, such as GHG emission monitoring, renewable energy development, carbon tax levy, environmental law legislation, and climate policy implementation. All in all, future study on social-environmental analysis and multidisciplinary approach are essential and may provide an appropriate recommendation for a lower human impacted environmental development.

\section{Conclusions}

In this study, a social-environmental approach was used to analyze the issue of $\mathrm{CH}_{4}$ in the SCS. The economic drivers and human activities that cause pressure on the environment and increase $\mathrm{CH}_{4}$ emissions in the region are analyzed. These economic drivers and human activities are urbanization and increases in MSW production, economic growth, lifestyle change, increasing size of animal farming and aquaculture, rapid industrial development and development of the bio-economy, and agricultural intensification. They impose environmental pressures by increasing the COD of water that is discharged into the SCS and increasing organic matter and $\mathrm{CH}_{4}$ concentrations in rivers and the SCS. This research provides information about changes in environmental state based on available scientific data, and in particular on increased $\mathrm{CH}_{4}$ concentrations and reduced DO concentrations 
in the SCS, increased temperatures as a result of the greenhouse effect of $\mathrm{CH}_{4}$, and destabilization of the seabed.

The possible future impact of climate change on human welfare is also discussed. These possible future impacts are reduced commercial fish hauls, increased vulnerability of coastal populations, potential collapse of offshore structures, new job opportunities and increased energy security as a result of the extraction of gas hydrates, and escalation of geopolitical tensions because of valuable maritime resources.

Finally, possible societal responses and management measures that can be implemented to reduce $\mathrm{CH}_{4}$ emissions in the SCS are identified. The responses are education, research into the exploitation of $\mathrm{CH}_{4}$ gas hydrates, the development of the circular economy, the construction of infrastructure, the implementation of new technology and agricultural technologies, a reduction of agrochemicals and fertilizer use, and the implementation of governance measures.

\section{Acknowledgements}

The authors wish to thank the Ministry of Science and Technology of the ROC, Taiwan (MOST 105-2611-M-110-017 and MOST 105-2119-M-110-004) and the Aim for the Top University Program Project (05C 030204 and 06C 030203), for supporting this research. The first author thanks the international grant from Bank Santander/UNESCO Chair UNITWIN/WiCop and the Erasmus Mundus Programme for the MACOMA Doctoral funding contract (SGA 20121701/001-001-EMJD). Alice Newton's research was partially supported by the Chinese Academy of Sciences (Yantai Institute of Coastal research professorship), DEVOTES project (EU 7FP grant agreement $\mathrm{n}^{\circ}$ 308392), and Future Earth Coasts. AVB is a senior research associate at the Fonds National de la Recherche Scientifique (FNRS).

\section{References}

Aktar, M.W., Sengupta, D., and Chowdhury, A. 2009. Impact of pesticides use in agriculture: their benefits and hazards. Interdiscip. Toxicol. 2(1): 1-12. doi: 10.2478/v10102-009-0001-7. PMID: 21217838.

Ali, M.A., Lee, C.H., and Kim, P.J. 2008. Effect of silicate fertilizer on reducing methane emission during rice cultivation. Biol. Fertil. Soils, 44: 597-604. doi: 10.1007/s00374-007-0243-5.

Allison, E.H., Perry, A.L., Badjeck, M.-C., Adger, W.N., Brown, K., Conway, D., et al. 2009. Vulnerability of national economies to the impacts of climate change on fisheries. Fish Fish, 10: 173-196. doi: 10.1111/j.1467-2979. 2008.00310.x.

Amundson, R. 2001. The carbon budget of soils. Annu. Rev. Earth Planet Sci. 29: 535-562. doi: 10.1146/annurev. earth.29.1.535

Archer, D. 2007. Methane hydrate stability and anthropogenic climate change. Biogeosciences, 4: 521-544. doi: $10.5194 /$ bg-4-521-2007.

Archer, D., Buffett, B., and Brovkin, V. 2009. Ocean methane hydrates as a slow tipping point in the global carbon cycle. Proc. Natl. Acad. Sci. USA, 106(49): 20596-20601. doi: 10.1073/pnas.0800885105. PMID: 19017807.

Asian Development Bank (ADB). 2011. Fast facts: urbanization in Asia. Asian Development Bank, Manila, Philippines.

Atkins, J.P., Burdon, D., Elliott, M., and Gregory, A.J. 2011. Management of the marine environment: integrating ecosystem services and societal benefits with DPSIR framework in a systems approach. Mar. Pollut. Bull. 62: 215-226. doi: 10.1016/j.marpolbul.2010.12.012.

Bajpai, P. 2016. Chapter 2 - Global pulp and paper production and consumption. Pulp Paper Indus. 2016: 9-14. doi: 10.1016/B978-0-12-803411-8.00002-0.

Bange, H.W. 2006. Nitrous oxide and methane in European coastal waters. Estuarine, Coastal Shelf Sci. 70: 361-374. doi: 10.1016/j.ecss.2006.05.042.

Bange, H.W., Bartell, U.H., Rapsomanikisa, S., and Andreae, M.O. 1994. Methane in the Baltic and North Seas and a reassessment of the marine emissions of methane. Global Biogeochem. Cycles, 8(4): 465-480. doi: 10.1029/ 94GB02181.

Barnosky, A.D. 2008. Colloquium Paper: Megafauna biomass tradeoff as a driver of Quaternary and future extinctions. Proc. Natl. Acad. Sci. USA, 105: 11543-11548. doi: 10.1073/pnas.0801918105. PMID: 18695222.

Ben Rais Lasram, F., Guilhaumon, F., Albouy, C., Somot, S., Thuiller, W., and Mouillot, D. 2010. The Mediterranean Sea as a 'cul-de-sac' for endemic fishes facing climate change. Glob. Chang. Biol. 16: 3233-3245. doi: 10.1111/j.13652486.2010.02224.x.

Bewers, J.M., and Pernetta, J.C. 2013. Special issue on South China Sea Project. Ocean Coast Manage. 85: 268-275. doi: 10.1016/j.ocecoaman.2012.12.008. 
Blanchard, J., Jennings, S., Holmes, R., Harle, J., Merino, G., Allen, J.I., et al. 2012. Potential consequences of climate change for primary production and fish production in large marine ecosystems. Philos. Trans. R. Soc. Lond. B Biol. Sci. 367: 2979-2989. doi: 10.1098/rstb.2012.0231. PMID: 23007086.

Boetius, A., and Suess, E. 2004. Hydrate ridge: a natural laboratory for the study of microbial life fueled by methane from near-surface gas hydrates. Chem. Geol. 205: 291-310. doi: 10.1016/j.chemgeo.2003.12.034.

Boetius, A., Ravenschlag, K., Schubert, C.J., Rickert, D., Widdel, F., Gieseke, A., et al. 2000. A marine microbial consortium apparently mediating anaerobic oxidation of methane. Nature, 407: 623-626. doi: 10.1038/35036572. PMID: 11034209.

Boopathy, R. 1998. Biological treatment of swine waste using anaerobic baffled reactors. Bioresour. Technol. 64(1): 1-6. doi: 10.1016/S0960-8524(97)00178-8.

Borges, A.V., and Abril, G. 2011. Carbon dioxide and methane dynamics in estuaries. In Treatise on estuarine and coastal science - Volume 5: Biogeochemistry. Edited by E. Wolanski and D. McLusky. Academic Press, Waltham, Mass. pp. 119-161.

Borges, A.V., Darchambeau, F., Teodoru, C.R., Marwick, T.R., Tamooh, F., Geeraert, N., et al. 2015. Globally significant greenhouse gas emissions from African inland waters. Nat. Geosci. 8: 637-642. doi: 10.1038/ngeo2486.

Borges, A.V., Champenois, W., Gypens, N., Delille, B., and Harlay, J. 2016. Massive marine methane emissions from near-shore shallow coastal areas. Sci. Rep. 6: 27908. doi: 10.1038/srep27908. PMID: 27283125.

Borges, A.V., Speeckaert, G., Champenois, W., Scranton, M.I., and Gypens, N. 2017. Productivity and temperature as drivers of seasonal and spatial variations of dissolved methane in the Southern Bight of the North Sea, Ecosystems. Ecosystems, 21: 583-599. doi: 10.1007/s10021-017-0171-7.

Borja, A., Galparsoro, I., Solaun, O., Muxika, I., Tello, E.M., Uriarte, A., and Valencia, V. 2006. The European Water Framework Directive and the DPSIR, a methodological approach to assess the risk of failing to achieve good ecological status. Estuarine, Coastal Shelf Sci. 66(1-2): 84-96. doi: 10.1016/j.ecss.2005.07.021.

Boswell, R. 2009. Is gas hydrate energy within reach? Science, 325: 957-958. doi: 10.1126/science.1175074. PMID: 19696340.

Brewer, P.G., Orr, F.M., Jr., Friederich, G., Kvenvolden, K. A., Orange, D. L., McFarlane, J., and Kirkwood, W. 1997. Deepocean field test of methane hydrate formation from a remotely operated vehicle. Geology, 25: 407-410, doi: 10.1130/0091-7613(1997)025<0407:DOFTOM>2.3.CO;2.

Cai, Z., Tsuruta, H., Gao, M., Xu, H., and Wei, C. 2003. Options fro mitigating methane emission from a permanently flooded rice field. Glob. Chang. Biol. 9: 37-45. doi: 10.1046/j.1365-2486.2003.00562.x.

Catley, B., and Keliat, M. 1997. Spratlys: the Dispute in the South China Sea. Ashgate, Brookfield, Vt.

Chao, S.Y., Shaw, P.T., and Wu, S.Y. 1996. Deep water ventilation in the South China Sea. Deep Sea Res. Part 1 Oceanogr. Res. Pap. 43: 445-466. doi: 10.1016/0967-0637(96)00025-8.

Chen, C.T.A. 2008. Buoyancy leads to high productivity of the Changjiang diluted water: a note. Acta Oceanol. Sin. 27: 133-140.

Chen, C.T.A., and Tseng, H.C. 2006. Abnormally high $\mathrm{CH}_{4}$ concentrations in seawater at mid-depths on the continental slops of the northern South China Sea. Terr. Atmos. Ocean Sci. 17: 951-959. doi: 10.3319/TAO.2006.17.4.951(GH).

Chen, C.T.A., Wang, S.L., Wang, B.J., and Pai, S.C. 2001. Nutrient budgets for the South China Sea basin. Mar. Chem. 75: 281-300. doi: 10.1016/S0304-4203(01)00041-X.

Chen, C.T.A., Hou, W.P., Gamo, T., and Wang, S.L. 2006a. Carbonate-related parameters of subsurface waters in the West Philippine, South China and Sulu Seas. Mar. Chem. 99: 151-161. doi: 10.1016/j.marchem.2005.05.008.

Chen, C.T.A., Wang, S.L., Chou, W.C., and Sheu, D.D. 2006b. Carbonate chemistry and projected future changes in $\mathrm{pH}$ and $\mathrm{CaCO}_{3}$ saturation state of the South China Sea. Mar. Chem. 101: 277-305. doi: 10.1016/j.marchem. 2006.01.007.

Chen, C.T.A., Wang, S.L., Lu, X.X., Zhang, S.R., Lui, H.K., Tseng, H.C., Wang, B.J., and Huang, H.I. 2008. Hydrogeochemistry and greenhouse gases of the Pearl River, its estuary and beyond. Quarter. Int. 186(1): 79-90. doi: 10.1016/j.quaint.2007.08.024.

Chen, C.T.A., Huang, T.H., Fu, Y.H., Bai, Y., and He, X. 2012. Strong sources of $\mathrm{CO}_{2}$ in upper estuaries become sinks of $\mathrm{CO}_{2}$ in large river plumes. Curr. Opin. Environ. Sustain, 4(2): 179-185. doi: 10.1016/j.cosust.2012.02.003.

Chen, D.F., Huang, Y.Y., Feng, D., and Su, Z. 2005. Seep carbonate and preserved bacteria fossils in the northern South China Sea and their geological implications. Bull. Miner. Petrol. Geochem. 24: 185-189 [In Chinese].

Chen, S. 2013. Environmental cooperation in the South China Sea: factors, actors and mechanisms. Ocean Coast Manage. 85: 131-140. doi: 10.1016/j.ocecoaman.2013.02.004.

Cheng, W.W.L., Inubushi, K., Yagi, K., Sakai, H., and Kobayashi, K. 2001. Effect of elevated $\mathrm{CO}_{2}$ on biological nitrogen fixation, nitrogen mineralization and carbon decomposition in submerged rice soil. Biol. Fertil. Soils, 34: 7-13. doi: 10.1007/s003740100345.

Cheung, W.W.L., Lam, V.W.Y., Sarmiento, J.L., Kearney, K., Watson, R., Zeller, D., and Pauly, D. 2010. Large-scale redistribution of maximum fisheries catch potential in the global ocean under climate change. Glob. Chang. Biol. 16: 24-35. doi: 10.1111/(ISSN)1365-2486.

Cheung, W.W.L., Watson, R., and Pauly, D. 2013. Signature of ocean warming in global fisheries catch. Nature, 497: 365-368. doi: 10.1038/nature12156. PMID: 23676754.

Chinadialogue. 2011. Report on environment health in the Pearl River Delta. Published by German Asia Foundation in cooperation with chinadialogue and the "EU-China Civil Society Dialogue on Participatory Public Policy. pp. 1-28.

Chou, W.C., Sheu, D.D.D., Chen, C.T.A., Wang, S.L., and Tseng, C.M. 2005. Seasonal variability of carbon chemistry at the SEATS timeseries site, northern South China Sea between 2002 and 2003. Terr. Atmos. Ocean Sci. 16(2): 445-465. doi: 10.3319/TAO.2005.16.2.445(O). 
Chua, T.E., Paw, J.N., and Guarin, F.Y.1989. The environmental impact of aquaculture and the effects of pollution on coastal aquaculture development in Southeast Asia. Mar. Pollut. Bull. 20(7): 335-343. doi: 10.1016/0025-326X(89) 90157-4.

Debenay, J.-P., and Luan, B.T. 2006. Foraminiferal assemblages and the confinement index as tools for assessment of saline intrusion and human impact in the Mekong Delta and neighboring areas (Vietnam). Rev. Micropaleontol. 49(2): 74-85. doi: 10.1016/j.revmic.2006.01.002.

Delgado, C., Rosegrant, M., Steinfeld, H., Ehui, S., and Courbois, C. 1999. Livestock to 2020: The next food revolution. International Food Policy Research Institute, Food and Agriculture Organisation of the United Nations, International Livestock Research Institute, Washington, DC.

Deng, L., Zhu, G.Y., Tang, Z.S., and Shangguan, Z.P. 2016. Global patterns of the effects of land-use changes on soil carbon stocks. Glob. Ecol. Conserv. 5: 127-138. doi: 10.1016/j.gecco.2015.12.004.

Diaz, R.J., and Rosenberg, R. 2008. Spreading dead zones and consequences for marine ecosystems. Science, 321: 926-929. doi: 10.1126/science.1156401. PMID: 18703733.

Dickens, G.R., and Quinby-Hunt, M.S. 1994. Methane hydrate stability in seawater. Geophys. Res. Lett. 21: $2115-2118$. doi: 10.1029/94GL01858.

Directorate-General of Budget, Accounting and Statistics, Executive Yuan, R.O.C. (Taiwan). 2018. Global reach: achieving quality. Available from http://eng.dgbas.gov.tw/.

Driscoll, N.W., Weissel, J.K., and Goff, J.A. 2000. Potential for largescale submarine slope failure and tsunami generation along the US mid-Atlantic coast. Geology, 28(5): 407-410. doi: 10.1130/0091-7613(2000)28<407:PFLSSF >2.0. $\mathrm{CO} ; 2$.

Du, S., Mroza, T.A., Zhai, F., and Popkin, B.M. 2004. Rapid income growth adversely affects diet quality in China Particularly for the poor! Soc. Sci. Med. 59: 1505-1515. doi: 10.1016/j.socscimed.2004.01.021. PMID: 15246178.

Dubber, D., and Gray, N.F. 2010. Replacement of chemical oxygen demand (COD) with total organic carbon (TOC) for monitoring wastewater treatment performance to minimize disposal of toxic analytical waste. J. Environ. Sci. Health A Tox. Hazard Subst. Environ. Eng. 45(12): 1595-1600. doi: 10.1080/10934529.2010.506116. PMID: 20721800.

EC (European Commission). 2013. Report from the commission to the European parliament, the council, the European economic and social committee and the committee of the regions. Seventh Report on the Implementation of the Urban Waste Water Treatment Directive. EEC Report.

EEA. 2005. European Environment Agency, Source apportionment of nitrogen and phosphorus inputs into the aquatic environment. EEA Report No 7/2005. European Environment Agency, Denmark.

EEA. 2015. European Environment Agency, State of Europe's seas. EEA Report No 2/2015. European Environment Agency, Denmark.

Elliott, M. 2002. The role of the DPSIR approach and conceptual models in marine environmental management: an example for offshore wind power. Mar. Pollut. Bull. 44: iii-vii. doi: 10.1016/S0025-326X(02)00146-7. PMID: 12146842.

EPA. 2004. Environmental protection agency, primer for municipal wastewater treatment systems. United States Environmental Protection Agency, Office of Water, Office of Wastewater Management, Washington, DC 20460.

FAO. 2006. FAO statistical databases. Available from http://faostat.fao.org/default.aspx.

FAO. 2011. Women in agriculture. FAO, Rome. Available from http://www.fao.org/catalog/inter-e.htm.

FNR (Fachagentur Nachwachsende Rohstoffe e.V). 2009. Very short but comprehensive overview of the biogas situation in Germany. Biogas Basisdaten Deutschland - Stand: Oktober 2008. 7 p.

GAIN (Global Agricultural Information Network). 2014. USDA Foreign agricultural service report. pp. 1-17.

Gari, S.R., Newton, A., and Icely, J.D. 2015. A review of the application and evolution of the DPSIR framework with an emphasis on coastal social-ecological systems. Ocean Coastal Manage. 103: 63-77. doi: 10.1016/j.ocecoaman. 2014.11.013.

Gerber, P., Chilonda, P., Franceschini, G., and Menzi, H. 2005. Geographical determinants and environmental implications of livestock production intensification in Asia. Bioresour. Technol. 96: 263-276. doi: 10.1016/j.biortech. 2004.05.016. PMID: 15381225.

González, C., Marciniak, J., Villaverde, S., García-Encina, P.A., and Muñoz, R. 2008. Microalgae-based processes for the biodegradation of pretreated piggery wastewaters. Appl. Microbiol. Biotechnol. 80: 891-898. doi: 10.1007/ s00253-008-1571-6.

Gray, J.S., and Elliott, M. 2009. Ecology of marine sediments - From science to management. 2nd ed. Oxford University Press, Oxford, UK.

Guangdong Agriculture Statistics. 2016. Available from http://www.gdstats.gov.cn/.

Han, X., Suess, E., Huang, Y., Wu, N., Bohrmann, G., Su, X., Eisenhauer, A., Rehder, G., and Fang, Y. 2008. Jiulong methane reef: microbial mediation of seep carbonates in the South China Sea. Mar. Geol. 249: 243-256. doi: 10.1016/j.margeo.2007.11.012.

Henze, M., Harremoes, P., Jansen, J.C., and Arvin, E. 2001. Wastewater treatment: biological and chemical processes. Springer Berlin Heidelberg.

Hill, D.T., and Bolte, J.P. 2000. Methane production from low solid concentration liquid swine waste using conventional anaerobic fermentation. Bioresour. Technol. 74(3): 241-247. doi: 10.1016/S0960-8524(00)00008-0.

Hill, R.D., Owen, N.G., and Roberts, E.V. (eds.) 1991. Fishing in troubled waters. Proc. An Academic Conference on Territorial Claims in the South China Sea, Hong Kong, Centre of Asian Studies. The University of Hong Kong, Hong Kong.

Hishamunda, N., Ridler, N.B., Bueno, P., and Yap, W. G. 2009. Commercial aquaculture in Southeast Asia: some policy lessons. Food Policy, 34: 102-107. doi: 10.1016/j.foodpol.2008.06.006. 
Holm-Nielsen, J.B., Al Seadi, T., and Oleskowicz-Popiel, P. 2009. The future of anaerobic digestion and biogas utilization. Bioresour. Technol. 100: 5478-5484. doi: 10.1016/j.biortech.2008.12.046. PMID: 19217772.

Holmen and its World. 2009. Sustainability report. 64 pp.

Hopkins, T.S., Bailly, D., and Støttrup, J.G. 2011. A systems approach framework for coastal zones. Ecol. Soc. 16(4). doi: 10.5751/ES-04553-160425.

Howarth, R.W. 2008. Coastal nitrogen pollution: a review of sources and trends globally and regionally. Harmful Algae, 8: 14-20. doi: 10.1016/j.hal.2008.08.015.

Hsu, H.H., Chern, W.S., and Gale, F. 2002. How will rising income affect the structure of food demand? In China's food and agriculture: Issues for the 21st century. Edited by F. Gale. Economic research service/USDA, Washington, DC.

Huang, J., Rozell, S., and Rosegrant, M.W.1999. China's food economy to the twenty-first century; supply, demand, and trade. Econ. Dev. Cult. Change, 47: 737-766. doi: 10.1086/452430.

Ince, B. K., Cetecioglu, Z., and Ince, O. 2011. Pollution prevention in the pulp and paper industries, environmental management in practice. Edited by E. Broniewicz. InTech. Available from http://www.intechopen.com/books/ environmental-management-in-practice/pollutionprevention-in-the-pulp-and-paper-industries.

Indonesia Investments. 2014. Pulp \& Paper Industry in Indonesia: Expand on Rising Demand from China (on line). Available from: https://www.indonesia-investments.com/news/todays-headlines/pulp-paper-industry-in-indonesiaexpand-on-rising-demand-from-china/item2349?

IPCC (Climate Change). 2013. The Physical Science Basis, Contribution of Working Group I to the Fifth Assessment Report of the Intergovernmental Panel on Climate Change.

IPCC (Climate Change). 2014. Synthesis report, Contribution of Working Group I, II and III to the Fifth Assessment Report of the Intergovernmental Panel on Climate Change.

Jobbágy, E.G., and Jackson, R.B. 2000. The vertical distribution of soil organic carbon and its relation to climate and vegetation. Ecol. Appl. 10: 423-436. doi: 10.1890/1051-0761(2000)010[0423:TVDOSO]2.0.CO;2.

Kennedy, M., Mrofka, D., and von der Borch, C. 2008. Snowball Earth termination by destabilization of equatorial permafrost methane clathrate. Nature, 453(7195): 642-645. doi: 10.1038/nature06961. PMID: 18509441.

Kim, H., Lim, H., and Colosimo, M.F. 2007. Determination of chemical oxygen demand (COD) using ullrasound digestion and oxidationreduction potential-based titration. J. Environ. Sci. Health A Tox. Hazard Subst. Environ. Eng. 42(11): 1665-1670. doi: 10.1080/10934520701518190. PMID: 17849309.

Kirschke, S., Bousquet, P., Ciais, P., Saunois, M., Canadell, J.G., Dlugokencky, E.J., et al. 2013. Three decades of global methane sources and sinks. Nat. Geosci. 6: 813-823. doi: 10.1038/ngeo1955.

Kivimaki, T. 2002. War or Peace in the South China Sea. The Nordic Institute of Asian Studies Press, Copenhagen, Denmark.

Komiya, S., Noborio, K., Katano, K., Pakoktom, T., Siangliw, M., and Toojinda, T. 2015. Contribution of ebullition to methane and carbon dioxide emission from water between plant rows in a tropical rice paddy field. Int. Sch. Res. Notices, 2015(623901): 1-8. doi: 10.1155/2015/623901.

Krans, R. 2015. Smart fertilizer use: a vegetable garden begins with a soil management plan. Michigan State University Extension.

Kvenvolden, K.A. 1999. Potential effects of gas hydrate on human welfare. Proc. Natl. Acad. Sci. USA, 96: 3420-3426. doi: 10.1073/pnas.96.7.3420. PMID: 10097052.

Liu, J., and Savenije, H.H.G. 2008. Food consumption patterns and their effect on water requirement in China. Hydrol. Earth Syst. Sci. 12: 887-898. doi: 10.5194/hess-12-887-2008.

Liu, S.M., Hong, G.H., Ye, X.W., Zhang, J., and Jiang, X.L. 2009. Nutrient budgets for large Chinese estuaries and embayment. Biogeosci. Discuss. 6: 391-435. doi: 10.5194/bgd-6-391-2009.

Lu, L.-T., Hsiao, T.-Y., Shang, N.-C., Yu, Y.-H., and Ma, H.-W. 2006. Country report: MSW management for waste minimization in Taiwan: the last two decades. Waste Manage. 26: 661-667. doi: 10.1016/j.wasman.2005.10.005.

Lui, H.K., and Chen, C.T.A. 2012. The nonlinear relationship between nutrient ratios and salinity in estuarine ecosystems: implications for management. Curr. Opin. Environ. Sustain, 4: 227-232. doi: 10.1016/j.cosust.2012.03.002.

Lui, H.K., Chen, C.T.A., Lee, J., Bai, Y., and He, X. 2014. Looming hypoxia on outer shelves caused by reduced ventilation in the open oceans: case study of the East China Sea. Estuarine, Coastal Shelf Sci. 151: 355-360. doi: 10.1016/j.ecss. 2014.08.010.

Maxim, L., Spangenberg, J.H., and O'Connor, M. 2009. An analysis of risks for biodiversity under the DPSIR framework. Ecol. Econ. 69(1): 12-23. doi: 10.1016/j.ecolecon.2009.03.017.

Mittal, S.K., and Ratra, R.K. 2000. Toxic effect of metal ions on biochemical oxygen demand. Water Res. 34(1): 147-152. doi: 10.1016/S0043-1354(99)00104-9.

Montalvo, S.J. 1995. Treatment of swine wastes by a high-rate modified anaerobic — process (HRAMP). Bioresour. Technol. 53(3): 207-210. doi: 10.1016/0960-8524(95)00048-J.

Moral, R., Moreno-Caselles, J., Perez-Murcia, M.D., Perez-Espinosa, A., Rufete, B., and Paredes, C. 2005. Characterisation of the organic matter pool in manures. Bioresour. Technol. 96: 153-158. doi: 10.1016/j.biortech. 2004.05.003. PMID: 15381211.

Morton, B., and Blackmore, G. 2001. South China Sea. Mar. Pollut. Bull. 42(12): 1236-1263. doi: 10.1016/S0025-326X(01) 00240-5. PMID: 11827109.

Naqvi, S.W.A., Bange, H.W., Farías, L., Monteiro, P.M.S., Scranton, M.I., and Zhang, J. 2010. Marine hypoxia/anoxia as a source of $\mathrm{CH}_{4}$ and $\mathrm{N}_{2} \mathrm{O}$. Biogeosciences, 7(7): 2159-2190. doi: 10.5194/bg-7-2159-2010.

National Oceanic Administration. 2012. The bulletin of marine environmental status of China. Available from http://www.soa.gov.cn/zwgk/hygb/gjhyjgb/. 
Newton, A. 2012. A systems approach for sustainable development in coastal zones. Ecol. Soc. 17: 41.

Newton, A., Icely, J.D., Falcao, M., Nobre, A., Nunes, J.P., Ferreira, J.G., and Vale, C. 2003. Evaluation of eutrophication in the Ria Formosa coastal lagoon, Portugal. Cont. Shelf Res. 23: 1945-1961. doi: 10.1016/j.csr.2003.06.008.

Newton, A., Icely, J., Cristina, S., Brito, A., Cardoso, A.C., Colijn, F., et al. 2014. An overview of ecological status, vulnerability and future perspectives of European large shallow, semi-enclosed coastal systems, lagoons and transitional waters. Estuarine, Coastal Shelf Sci. 140: 95-122. doi: 10.1016/j.ecss.2013.05.023.

Ngoc, U.N., and Schnitzer, H. 2009. Sustainable solutions for solid waste management in Southeast Asian countries. Waste Manage. 29: 1982-1995. doi: 10.1016/j.wasman.2008.08.031.

Ni, H.-G., Lu, F.-H., Luo, X.-L., Tian, H.-Y., and Zeng, E. Y. 2008. Riverine inputs of total organic carbon and suspended particulate matter from the Pearl River Delta to the coastal ocean off South China. Mar. Pollut. Bull. 56: 1150-1157. doi: 10.1016/j.marpolbul.2008.02.030. PMID: 18374367.

O’Connor, F.M., Boucher, O., Gedney, N., Jones, C.D., Folberth, G.A., Coppell, R., et al. 2010. Possible role of wetlands, permafrost, and methane hydrates in the methane cycle under future climate change: a review. Rev. Geophys. 48(4).

Odgaard, L. 2002. Maritime security between China and Southeast Asia. Ashgate, Burlington, Vt.

Oil and Gas UK. 2018. Available from http://oilandgasuk.co.uk/.

OPL. 2000. South East Asia Oil \& Gas Activity and Concession Map. 2000 ed. Oilfield Publications, Herefordshire, England.

Ostrom, E. 2009. A general framework for analyzing sustainability of social-ecological systems. Science, 325: 419-422. doi: 10.1126/science.1172133. PMID: 19628857.

Ouyang, T., Zhu, Z., and Kuang, Y. 2006. Assessing impact of urbanization on river water quality in the Pearl River Delta economic zone, China. Environ. Monit. Assess. 120: 313-325. doi: 10.1007/s10661-005-9064-x. PMID: 16738781.

Patrício, J., Elliott, M., Mazik, K., Papadopoulou, K.-N., and Smith, C.J. 2016. DPSIR - Two decades of trying to develop a unifying framework for marine environmental management? Front. Mar. Sci. 3(177): 1-14. doi: 10.3389/fmars.2016.00177.

Pauly, D., Belhabib, D., Blomeyer, R., Cheung, W.W.W.L., Cisneros-Montemayor, A.M., Copeland, et al. 2014. China's distant-water fisheries in the 21st century. Fish Fish, 15: 474-488. doi: 10.1111/faf.12032.

Pernetta, J.C., and Bewers, J.M. 2013. Introduction to the special issue of coastal and ocean management entitled the South China Sea project: a multilateral marine and coastal area management initiative. Ocean Coast. Manage. 85: 127-130. doi: 10.1016/j.ocecoaman.2013.11.002.

Portner, H. O., and Knust, R. 2007. Climate change affects marine fishes through the oxygen limitation of thermal tolerance. Science, 315: 95-97. doi: 10.1126/science.1135471. PMID: 17204649.

Rabalais, N.N., Diaz, R.J., Levin, L.A., Turner, R.E., Gilbert, D., and Zhang, J. 2010. Dynamics and distribution of natural and human-caused hypoxia. Biogeosciences, 7: 585-619. doi: 10.5194/bg-7-585-2010.

Raymond, P.A., Bauer, J.E., Caraco, N.F., Cole, J.J., Longworth, B., and Petsch, S.T. 2004. Controls on the variability of organic matter and dissolved inorganic carbon ages in northeast US rivers. Mar. Chem. 92(1): 353-366. doi: 10.1016/ j.marchem.2004.06.036.

Rogers, S.I., and Greenaway, B. 2005. A UK perspective on the development of marine ecosystem indicators. Mar. Pollut. Bull. 50(1): 9-19. doi: 10.1016/j.marpolbul.2004.10.028. PMID: 15664029.

Saunois, M., Bousquet, P., Poulter, B., Peregon, A., Ciais, P., Canadell, J.G., et al. 2016. The global methane budget. Earth Syst. Sci. Data, 8: 697-751. doi: 10.5194/essd-8-697-2016.

Scranton, M.I., and McShane, K. 1991. Methane in the southern North Sea: the role of European rivers. Cont. Shelf Res. 11(1): 37-52. doi: 10.1016/0278-4343(91)90033-3.

Sea Around Us. 2007. A global database on marine fisheries and ecosystems. Fisheries Centre, University British Columbia, Vancouver, Canada. Available from www.seaaroundus.org/lme/SummaryInfo.aspx?LME=36.

Sethy, S., Sothun, C., and Wildblood, R. 2014. Municipal solid waste management in Cambodia. Municipal Solid Waste Management in Asia and the Pacific Islands. Springer Singapore. pp 77-94.

Seto, S.J. 2002. The River Story: Zhujiang. Hong Wen Goan Publications Inc., Kaohsiung, Taiwan. 567 pp [In Chinese].

Sha, Z., Liang, J., Zhang, G., Yang, S., Lua, J., Zhang, Z., McConnell, D.R., and Humphrey, G. 2015. A seepage gas hydrate system in northern South China Sea: seismic and well log interpretations. Mar. Geol. 366: 69-78. doi: 10.1016/j.margeo.2015.04.006.

Su, C.Y., Niu, B.H., Wang, H.Y., and Zhao, K.B. 2005. A study of gas hydrate geochemical exploration and deposit formation patterns in the Xisha ocean. Front Earth Sci. 12: 243-251 [In Chinese].

Su, J.J., Liu, B.Y., and Chang, Y.C. 2003. Emission of greenhouse gas from livestock waste and wastewater treatment in Taiwan. Agric. Ecosyst. Environ. 95: 253-263. doi: 10.1016/S0167-8809(02)00090-7.

Suess, E. 2005. RV SONNE cruise report SO 177, Sino-German cooperative project, South China Sea Continental Margin: geological methane budget and environmental effects of methane emissions and gashydrates. IFM-GEOMAR Reports. Available from http://store.pangaea.de/documentation/Reports/SO177.pdf.

Sunday, J.M., Bates, A.E., and Dulvy, N.K. 2011. Global analysis of thermal tolerance and latitude in ectotherms. Proc. R Soc. London B Biol. Sci. 278: 1823-1830. doi: 10.1098/rspb.2010.1295.

Tseng, H.C., Chen, C.T.A., Borges, A.V., DelValls, T.A., Lai, C.M., and Chen, T.Y. 2016. Distributions and sea-to-air fluxes of nitrous oxide in the South China Sea and the West Philippines Sea. Deep Sea Res. Part 1 Oceanogr. Res. Pap. 115: 131-144. doi: 10.1016/j.dsr.2016.06.006.

Tseng, H.C., Chen, C.T.A., Borges, A.V., DelValls, T.A., and Chang, Y.C. 2017. Methane in the South China Sea and the Western Philippine Sea. Cont. Shelf Res. 135: 23-34. doi: 10.1016/j.csr.2017.01.005. 
Tukker, A. 2015. Product services for a resource-efficient and circular economy — a review. J. Clean Prod. 97: 76-91. doi: 10.1016/j.jclepro.2013.11.049.

Upstill-Goddard, R.C., Barnes, J., Frost, T., Punshon, S., and Owens, N.J.P. 2000. Methane in the southern North Sea: low-salinity inputs, estuarine, and atmospheric flux. Global Biogeochem. Cycles, 14: 1205-1217. doi: 10.1029/ 1999GB001236.

Valencia, M.J. 1995. China and the South China Sea Disputes. Oxford University Press, Oxford, UK.

Vogt, P.R., and Jung, W.Y. 2002. Holocene mass wasting on upper non-Polar continental slopes- due to post-Glacial ocean warming and hydrate dissociation? Geophys. Res. Lett. 29(9): 55-1-55-4. doi: 10.1029/2001GL013488.

Wang, K., and Chen, T. 2009. Research on development characteristics of the extended metropolitan region in PRD. Trop. Geogr. 29(1): 31-36.

Warren, G.F. 1998. Spectacular increases in crop yields in the United States in the Twentieth Century. Weed Technol. 12: 752-760. doi: 10.1017/S0890037X00044663.

Witjesa, S., and Lozanoa, R. 2016. Towards a more Circular Economy: proposing a framework linking sustainable public procurement and sustainable business models. Resour. Conserv. Recy. 112: 37-44. doi: 10.1016/j. resconrec.2016.04.015.

The World Bank. 2012. Urban development and local government unit of the sustainable development network. The Urban Development Series: a Global Review of Solid Waste Management. Available from www.worldbank. org/urban.

The World Bank. 2015. China - Second Guangdong Pearl River Delta Urban Environment Project. World Bank Group, Washington, DC. Available from http://documents.worldbank.org/curated/en/185011475117527097/ China-Second-Guangdong-Pearl-River-Delta-Urban-Environment-Project.

Wu, S.G., Zhang, G.X., and Huang, Y.Y. 2005. Gas hydrate occurrence on the continental slope of the northern South China Sea. Mar. Petrol. Geol. 22: 403-412. doi: 10.1016/j.marpetgeo.2004.11.006.

Wu, S.G., Sun, Q.L., Wu, T.Y., Yuan, S.Q., Ma, Y.B., and Yao, G.S. 2009. Polygonal fault and oil-gas accumulation in deep-water area of Qiongdongnan Basin. Acta Petrolei Sin. 30: 22-32 [In Chinese].

Yan, X., Yagi, K., Akiyama, H., and Akimoto, H. 2005. Statistical analysis of the major variables controlling methane emission from rice fields. Glob. Chang. Biol. 11: 1131-1141. doi: 10.1111/j.1365-2486.2005.00976.x.

Yan, X., Akiyama, H., Yagi, K., and Akimoto, H. 2009. Global estimations of the inventory and mitigation potential of methane emissions from rice cultivation conducted using the 2006 Intergovernmental Panel on Climate Change guidelines. Global Biogeochem. Cycles, 23(2): GB2002. doi: 10.1029/2008GB003299.

Yeh, A.G.O., and Li, X. 1999. Economic development and agricultural land loss in the Pearl River Delta, China. Habitat Int. 23: 373-390. doi: 10.1016/S0197-3975(99)00013-2.

Yong, R. 2007. The circular economy in China. J. Mater. Cycles Waste, 9(2): 121-129. doi: 10.1007/s10163-007-0183-z.

Yuan, Z., Bi, J., and Moriguichi, Y. 2006. The circular economy. A new development strategy in China. J. Ind. Ecol. 10(1-2): 4-8. doi: 10.1162/108819806775545321.

Zhang, Y., and Zhai, W.-D. 2015. Shallow-ocean methane leakage and degassing to the atmosphere: triggered by offshore oil-gas and methane hydrate explorations. Front. Mar. Sci. 2: 34. doi: 10.3389/fmars.2015.00034.

Zhou, H., Yin, X., Yang, Q., Wang, H., Wu, Z., and Bao, S. 2009. Distribution, source and flux of methane in the western Pearl River Estuary and northern South China Sea. Mar. Chem. 117: 21-31. doi: 10.1016/j. marchem.2009.07.011. 